\title{
Seven new species and seven new records of Begonia $L$. (Begoniaceae) in the flora of Laos
}

\author{
K. Souvannakhoummane ${ }^{1,4}$, S. Lanorsavanh ${ }^{2,5}$, L. V. Averyanov ${ }^{3,6 *}$, V. Lamxay ${ }^{2,7}$ \\ ${ }^{1}$ Centre for Development and Environment, Lao Country Office, Unit 11, № 136, Simuang Road, Hom 1, P. O. Box 1438, Ban \\ Phapo, Vientiane, Lao PDR \\ ${ }^{2}$ Department of Biology, Faculty of Natural Science, National University of Laos, Vientiane, Lao PDR \\ ${ }^{3}$ Komarov Botanical Institute, Russian Academy of Sciences, Prof. Popova Str., 2, St.-Petersburg, 197376, Russian Federation \\ ${ }^{4}$ ORCID iD: https://orcid.org/0000-0003-4875-8307 \\ ${ }^{5}$ ORCID iD: https://orcid.org/0000-0002-8433-7297 \\ ${ }^{6}$ E-mail: av_leonid@mail.ru; ORCID iD: https://orcid.org/0000-0001-8031-2925 \\ ${ }^{7}$ ORCID iD: https://orcid.org/0000-0002-3849-8022 \\ * Corresponding author
}

Keywords: , local endemism, new species, plant diversity, plant taxonomy.

Summary. New species of Begonia L. in the flora of Laos presented in this paper were mainly found in the course of botanical surveys made in Hin Nam No National Protected Area, Nam Phouy National Protected Area, Khammouane Karst Forest, and Phou Khao Khouay National Protected Area. Additionally, herbaria presently available in Laos (HNL, FOF, NUoL, FRC), living plants, and alcohol preserved material at Pha Tad Ke Botanical Garden and the data accessible online at BM, E, K, LE, NY, P, and PE Herbaria were critically studied. The study conducted during 2012-2019 reveals seven new species for science and seven species newly recorded for the flora of Lao PDR. Species described as new for science are: B. glabritepala (found in Khammouane Province; it is most close to B. pierrei but differs in glabrous outer tepals of staminate flowers, pistillate flowers, capsules, petioles, peduncles and pedicles), B. heterocantha (found in Sainyabuli Province; most close to B. depingiana but differs in reddish purple, glandular pubescent abaxial leaf surface, glandular pubescent pedicel, and outer tepals of pistillate flowers sparsely white glandular pubescent), B. lanxangensis (found in Vientiane Province; most close to B. paleacea but differs in elongate tubers, ovate-lanceolate, obscurely asymmetrical to symmetrical leaves, and glabrous pedicels), $B$. parviglandulosa (found in Vientiane Province; most close to B. martabanica but differs in smaller habit, reniform-cordate leaves and glandular indumentum on peduncle, pedicle and capsules), B. pseudobrandisiana (found in Khammouane Province; most close to $B$. brandisiana but differs in pistillate flowers with five elliptic-oblanceolate tepals), $B$. tripartifolia (found in Khammouane Province; most close to B. tricuspidata but differs in leaves palmate triangular-ovate, with deeply lobed lacerate margin, pistillate flower of five tepals, and ovary with unequal wing), and B. viriditenebris (found in Khammouane Province; most close to $B$. sinuata but differs in single leaf, indumentum of bristle hairs and reddish or bronzy green adaxial leaf surface, and three styles). The following species discovered and recorded for the flora of Laos at first are: B. hatacoa (known in Nepal, Bhutan, NE India, Myanmar, Thailand, and Vietnam), B. hemsleyana (China, Vietnam), B. labordei (NE India, Myanmar, S China, Vietnam), B. longifolia (tropical zone from NE India to Indonesia), B. minuscula (Vietnam), B. parvula (S China), and B. subperfoliata (Myanmar, Thailand, $\mathrm{S}$ Vietnam). Descriptions and line drawings are provided for all newly described species. Photographic illustrations, data on phenology, habitat, and notes on morphological variations and relations are given for all studied species. 


\title{
Семь новых видов и семь новых находок бегоний (Begonia, Begoniaceae) во флоре Лаоса
}

\author{
К. Соуванакхоуман ${ }^{1}$, С. Ланорсаван², Л. В. Аверьянов ${ }^{3}$, В. Ламсай ${ }^{2}$ \\ ${ }^{1}$ Центр развития и окружающей среды, Государственный департамент, корпус 11, № 136, \\ Симуанг роад, 1, район Бан Фапо, г. Вьентьян, Лаос \\ 2 Департамент биологии, Факультет естественных наук, Национальный университет Лаоса, г. Вьентьян, Лаос \\ ${ }^{3}$ Ботанический институт им. В. Л. Комарова РАН, ул. Проф. Попова, д. 2, г. Санкт-Петербург, 197376, Россия
}

Ключевые слова: Индокитай, локальный эндемизм, новые виды, разнообразие растений, таксономия растений.

\begin{abstract}
Аннотация. Виды бегоний (Begonia L.), новые для флоры Лаоса, были найдены большей частью при проведении ботанических исследований на территориях заповедников Хин Нам Но, Нам Фоу, Карстовый лес Кхаммуан и Фоу Кхао Кхоай. В дополнение к полевым исследованиям критически изучены гербарные коллекции, имеющиеся в настоящее время в Лаосе (HNL, FOF, NUoL, FRC), живые растения и заспиртованные образцы ботанического сада Фа Тад Ке, а также данные гербариев BM, E, K, LE, NY, P и PE, доступные оnline. Исследование, проведенное в 2012-2019 гг., выявило семь новых видов для науки и семь видов, новых для флоры страны. Видами, новыми для науки, являются: Begonia glabritepala (найден в провинции Кхаммуан; наиболее близок к $B$. pierrei, но отличается голыми чашелистиками тычиночных цветков и полностью голыми пестичными цветками, плодами, черешками листьев, цветоносами и цветоножками), B. heterocantha (найден в провинции Сайнябули; наиболее близок к B. depingiana, но отличается пурпурной, железисто опушенной нижней стороной листа, железистым опушением цветоноса, беловатым, рассеянно железистым опушением чашелистиков пестичных цветков), B. lanxangensis (найден в провинции Вьентьян; наиболее близок к B. paleacea, но отличается удлиненными клубнями, узкояйцевидными симметричными или слегка асимметричными листьями и голыми цветоножками), B. parviglandulosa (найден в провинции Вьентьян; наиболее близок к B. martabanica, но отличается маленькими размерами, почковидно-сердцевидными листьями и железистым опушением цветоноса, цветоножек и плодов), B. pseudobrandisiana (найден в провинции Кхаммуан; наиболее близок к $B$. brandisiana, но отличается пестичными цветками, имеющими 5 узкоэллиптических листочков околоцветника), B. tripartifolia (найден в провинции Кхаммуан; наиболее близок к B. tricuspidata, но отличается глубоко рассеченными, яйцевидно-треугольными листьями с выгрызенным краем, 5-лепестковыми цветками и завязью с отчетливо неравными крыльями) и B. viriditenebris (найден в провинции Кхаммуан; наиболее близок к B. sinuata, но отличается наличием только одного щетинисто опушенного листа, бронзово-зеленовытым с верхней стороны и тремя столбиками рыльца). Следующие семь видов приводятся для флоры Лаоса впервые: B. hatacoa (область распространения вида: Непал, Бутан, С.-В. Индия, Мьянма, Таиланд и Вьетнам), B. hemsleyana (Ю. Китай, Вьетнам), B. labordei (С.-В. Индия, Мьянма, Ю. Китай, Вьетнам), B. longifolia (тропическая зона Азии от С.-В. Индии до Индонезии), B. minuscula (Вьетнам), B. parvula (Ю. Китай) и B. subperfoliata (Мьянма, Таиланд и Ю. Вьетнам). Детальные описания и черно-белые рисунки приводятся для видов, новых для науки. Для всех изученных видов приведены фотографии, данные о фенологии, экологии, морфологической изменчивости и предполагаемом ближайшем родстве.
\end{abstract}

\section{Introduction}

Lao begonias are still poorly studied and known by a few specimens available presently in the world herbaria. The preliminary plant checklist for Lao People's Democratic Republic (Lao PDR) listed 13 species of Begonia L. (Hughes, 2008). Later, eight new species have been described (De Wilde et al., 2011; Averyanov, Nguyen, 2012; Souvannakhoummane et al., 2016, 2018; Yang et al., 2018; Averyanov et al., 2019a, b), and one species (B. demissa Craib) have been reported as new species for the Laotian flora (Hughes et al., 2018). The last assessment (Hong-Bo et al., 2020a) indicates 26 Begonia species in the flora of Laos and provides an updated checklist of the genus with two new species for science, $B$. laotica $Y$. $\mathrm{H}$. Tan et H. B. Ding (B. sect. Parvibegonia A. de Candolle) and B. hypoleuca Y. H. Tan et H. B. Ding (B. sect. Reichenheimia (Klotzsch) A. AC.), as well as five taxa newly recorded in the country (B. augustinei Hemsl., B. dryadis Irmsch, B. lancangensis S. H. 
Huang, B. sizemoreae Kiew and B. silletensis (A. DC.) C. B. Clarke subsp. mengyangensis Tebbitt et K. Y. Guan). In the comparison with neighboring countries, floras of Myanmar includes 73 species (Hughes et al., 2019), Thailand - 47 (Phutthai, Hughes, 2017), China - 204 (Gu et al., 2007; Wang et al., 2019), and Vietnam - 73 accepted taxa (Ho, 1991; Hughes et al., 2015-, 2019; Peng et al., 2015a, b; Phutthai, Hughes, 2017; Moonlight et al., 2018).

This paper provides results of critical studies of herbaria presently available at the National Herbarium of Laos (HNL), National University of Laos (FOF), Biology Herbarium of the National University of Lao PDR (NUoL), Forest Research Central Herbarium of the National Agriculture and Forest Research Institute (FRC), as well as living plants and alcohol preserved material at Pha Tad Ke Botanical Garden. Additionally, relevant literature available online at the Begonia Resource (Hughes et al., 2015-) and Biodiversity Library website (https:// www.biodiversitylibrary.org/) was studied, along with specimen images available online at BM, E, K, LE, NY, P, and PE Herbaria. Keys and descriptions provided by Doorenbos et al. (1998) and Moonlight et al. (2018) were used for the identification of the genus sections. Completed investigation reveals seven new species for science and seven species newly recorded for the flora of Lao PDR. These discoveries are results of botanical surveys of Hin Nam No National Protected Area, Nam Phouy National Protected Area, Khammouane karst forest, and Phou Khao Khouay National Protected Area. Descriptions and line drawings are provided for all newly described species. Photographic illustrations, data on phenology, habitat, and notes on morphological variations and relations are given for all studied species.

\section{Begonia species new for science discovered in Lao PDR}

\footnotetext{
Begonia glabritepala Souvann. et Lanors., sp. nov.

(B. sect. Reichenheimia (Klotzsch) A. DC.)

Type: "Lao PDR, Khammouane Province, Boualapha District, Hin Nam No National Protected Area, $17^{\circ} 26^{\prime} 03.0^{\prime \prime} \mathrm{N}, 105^{\circ} 46^{\prime} 31.7^{\prime \prime} \mathrm{E}$, at elevation $280 \mathrm{~m}$ a. s. 1.8 X 2017. V. Lamxay, S. Lanorsavanh, K. Souvannakhoummane, S. Vongphachan, T. Keopunya, HNN 247" (HNL!; iso - KKU!).
}

Diagnosis. The species is similar to $B$. pierrei Gagnep. in habit but differs in having glabrous outer tepals of staminate flowers, pistillate flowers, capsules, petioles, peduncles, and pedicles (vs. all mentioned plant parts pilose) (Fig. 1, 2A).

Description. Monoecious tuberiferous herb, 7-14 cm tall. Tubers globose, 3-6 $\mathrm{mm}$ in diameter, dark gray, with solitary leaves and 1-2 inflorescences. Leaves solitary, lamina membranous, symmetrical, ovate or cordate, $2-5 \times 2.5-7 \mathrm{~cm}$, base cordate, acute, margin serrate with strigose hairs; adaxial surface green, sparsely strigose; abaxial surface pale green to purple, glabrous; venation palmate, veins $6-8$, prominent beneath. Petioles 3-7 mm long, fleshy, pale green, glabrous. Stipules persistent, membranous, broadly triangular, 1$1.5 \times 0.7-1.2 \mathrm{~mm}$, acute, margin slightly serrate with strigose hairs, both surfaces glabrous, light green. Inflorescence compound cyme arising from top of tubers, branched up to 3 times, bisexual, 5-8.5 cm long, staminate flowers distal, pistillate flowers basal, protandrous. Peduncles $3.2-6 \mathrm{~cm}$ long, glabrous, light green. Bracts narrowly elliptic, $1.5-2 \times 0.7-1 \mathrm{~mm}$, acuminate, margin with strigose hairs, both surfaces glabrous, pale green. Staminate flowers: pedicels 9-1.4 mm long, erect or ascending, glabrous, green; tepals 4 , white, outer pair broadly oblanceolate, $6.5-12 \times 6.5-7.5 \mathrm{~mm}$, apex rounded, both surfaces glabrous, inner pair oblanceolate, 10$13 \times 1.8-2 \mathrm{~mm}$, apex rounded, glabrous; stamens ca. 15, bright yellow, filaments ca. $1.2 \mathrm{~mm}$ long, free part ca. $0.5 \mathrm{~mm}$ long, anthers oblong, $2-1.2 \mathrm{~mm}$ long, dehiscing by longitudinal slits near the tip. Pistillate flowers: pedicels $8-12 \mathrm{~mm}$ long, glabrous, green; tepals 4 , white, outer pair, broadly ovate, $8-9 \times 3.2-6.5 \mathrm{~mm}$, glabrous, apex rounded, inner 2 subequal, narrowly oblanceolate, 5-6 $\times 0.5-1$ $\mathrm{mm}$, apex rounded, glabrous; ovary white, with 3 unequal wings; 3-locular, placentation axillary, one branch per locule; styles 3, connate at the middle into common stalk, dark yellow, stigmatic band kidneyshaped, papillulose. Capsules oblong-elliptic, 7$10 \times 4.4-5 \mathrm{~mm}$; locules subglobose, $0.8-1.2 \times 0.5-$ $1 \mathrm{~mm}$, dorsal wing trigonous, $4-8 \mathrm{~mm}$ tall, lateral wings $1-2.5 \mathrm{~mm}$ wide, glabrous, green, pale brown when dry. Seeds numerous, elliptic-obovate, 0.3$0.4 \times 0.1-0.2 \mathrm{~mm}$, testa reticulate, light brown.

Distribution. This species is endemic to Hin Nam No National Protected Area (Khammouane Province, Boualapha District).

Ecology and phenology. Wet rock crevices in humid places of limestone deciduous forest. Flowers from August to October, fruits in October.

Vernacular name. Som Saeng Pha (hill begonia). 


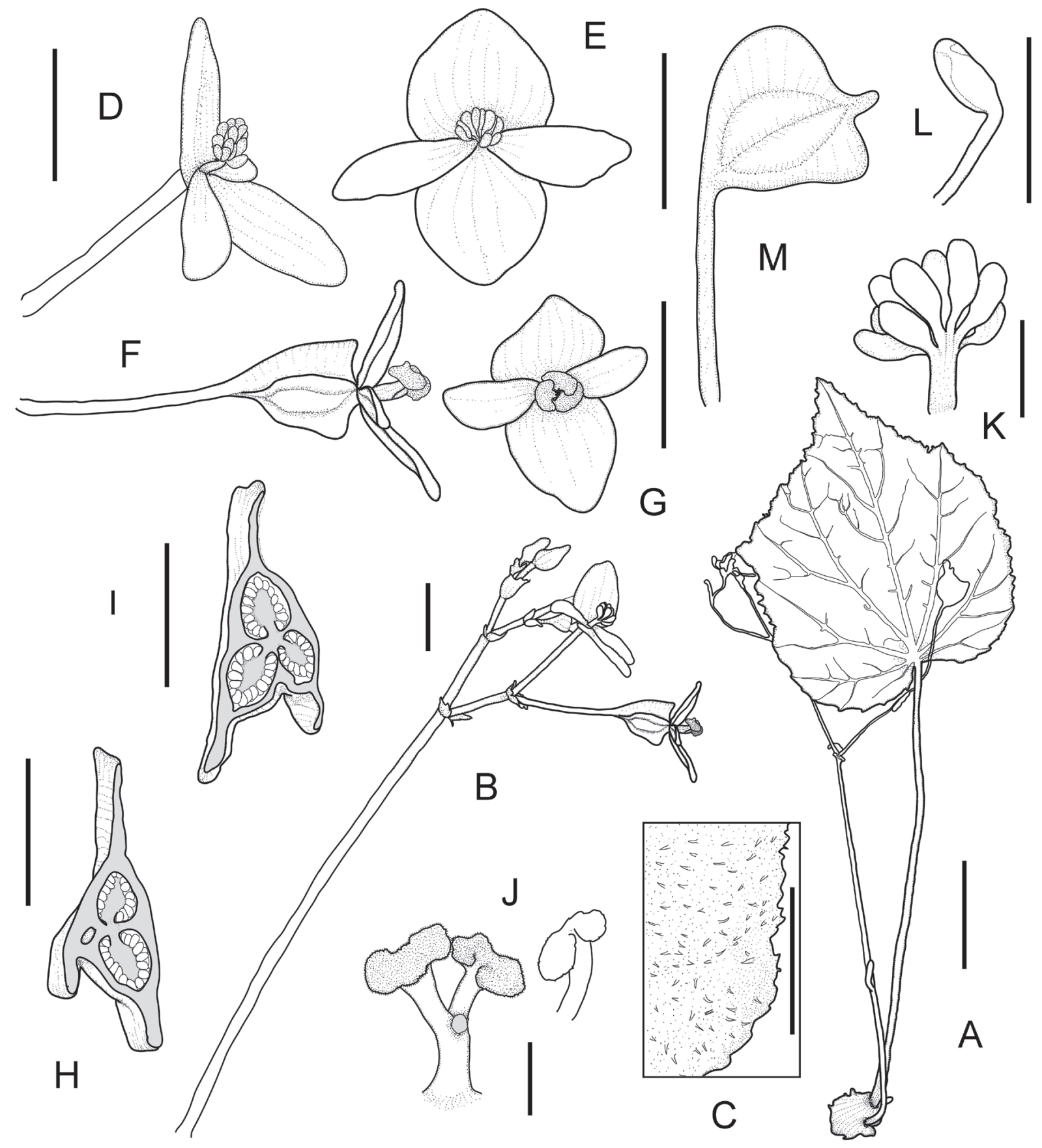

Fig. 1. Begonia glabritepala Souvann. et Lanors.: A - Fruiting plant; B - Inflorescence; C - Marginal portion of leaf, adaxial surface and margin; D, E - Staminate flowers, side and frontal views; F, G - Pistillate flowers, side and frontal views; H - Ovary, cross section; I - Mature capsule, cross section; J - Style and stigmatic band, ventral and dorsal views; K - Stamens; L - anther, side view; M - Capsule, lateral view. Scale bars: A - 2 cm; B-I, M - $1 \mathrm{~cm}$; J-L $1 \mathrm{~mm}$. Drawn by K. Souvannakhoummane.

Notes. The new species belongs to $B$. sect. Reichenheimia, which includes 22 species in SE Asia, including our new species. All species of the section are tuberiferous plants having flowers with 3 stigmas, 3-locular ovary, and placental branches
1 per locule. Described species has hairy adaxial surface and margin of leaves, but other parts of plant are glabrous. The specific epithet refers to glabrous tepals. 

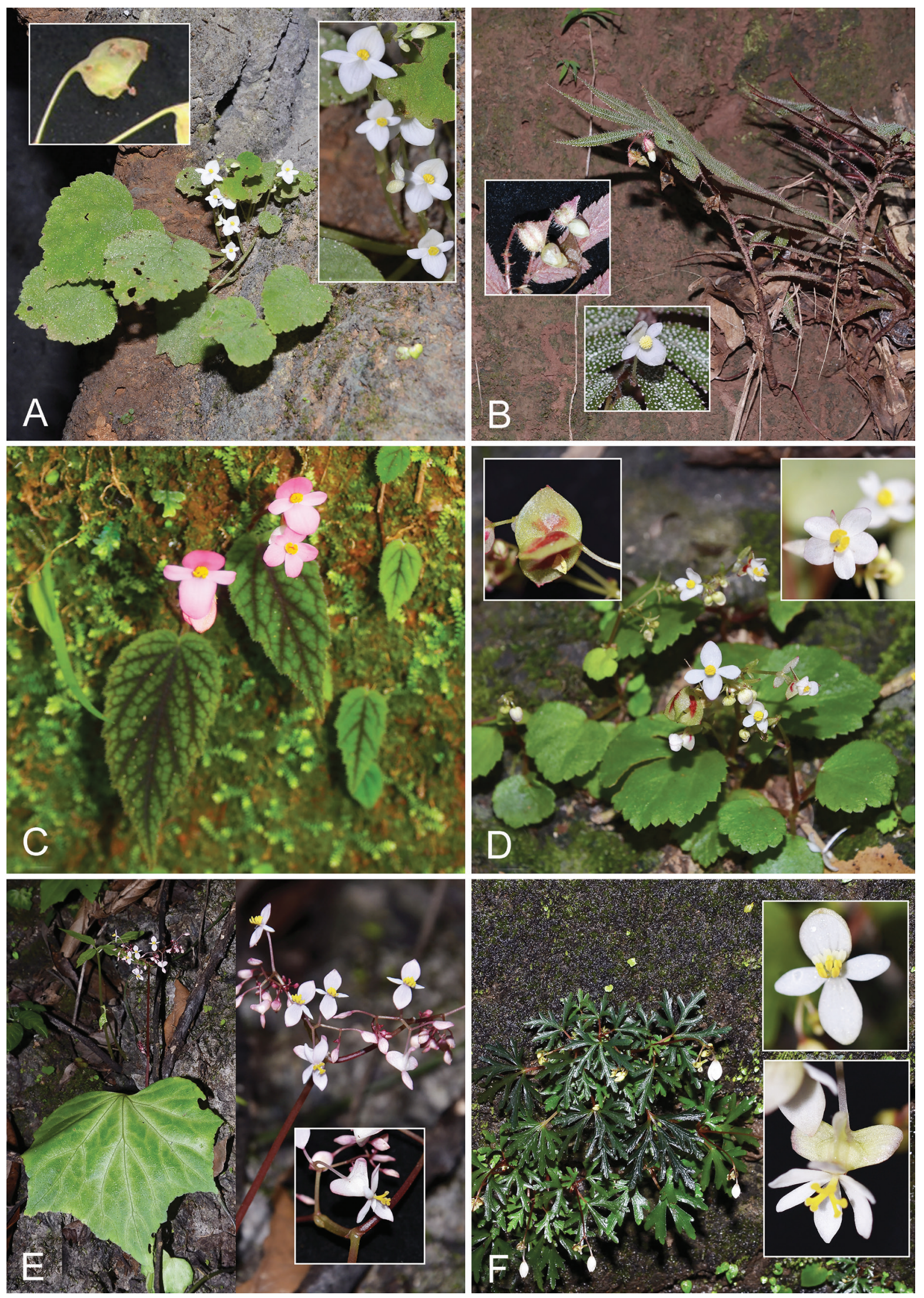

Fig. 2. Begonia glabritepala Souvann. et Lanors.: A - Flowering plant in natural habitat, flowers and capsule. $B$. heteracantha Souvann. et Lanors.: B - Flowering plant in natural habitat, flower and capsules. B. lanxangensis Souvann. et Aver.: C - Flowering plants in natural habitat. B. parviglandulosa Souvann. et Lanors.: D - Flowering plants in natural habitat, pistillate flowers and capsule. B. pseudobrandisiana Souvann. et Lanors.: E - Flowering plant in natural habitat, inflorescence and pistillate flower. F - B. tripartifolia Souvann. et Lanors.: A - Flowering plant in natural habitat and flowers. Photographs by S. Lanorsavanh (A, B, D-F) and K. Souvannakhoummane (C). 
Proposed IUCN (2019) category. Vulnerable (VU B1, 2ab (i, ii, v)). Begonia glabritepala is known only from the type locality within Hin Nam No Protected Area. The known species area of occupancy is $4 \mathrm{~km}^{2}$ and extent of occupancy is $820 \mathrm{~km}^{2}$. The individuals form less than 5 colonies. Hence, we consider B. glabritepala to be Vulnerable under the VU B1 and 2 criteria.

Begonia heterocantha Souvann. et Lanors., sp. nov.

(B. sect. Lauchea (Klotzsch) A. DC.)

Type: "Lao PDR, Sainyabuli Province, Thongmixay District, Nam Phouy National Protected Area, $18^{\circ} 19^{\prime} 20.8^{\prime \prime} \mathrm{N}, 101^{\circ} 15^{\prime} 0.07^{\prime \prime} \mathrm{E}$, at elevation $280 \mathrm{~m}$ a. s. 1., 29 IX 2018, Lanorsavanh S., Lamxay V., SL 1512" (HNL!; iso - FOF!, KKU!, QBG!).

Diagnosis. This species is close to $B$. depingiana Y. H. Tan et H. B. Ding in its tuberiferous habitus, distichous alternate leaves, and 3-locular ovary (Hong-Bo et al., 2020b). From mentioned species, it differs in reddish purple, glandular pubescent abaxial leaf surface (vs. abaxial surface light green, densely white villous), glandular pubescent pedicel (vs. pedicel puberulous), and outer tepals of pistillate flowers sparsely white glandular pubescent (vs. tepals almost glabrous, light pinkish) (Fig. 2B, 3).

Description. Monoecious tuberiferous herb, $8-25 \mathrm{~cm}$ tall. Tubers oblate or globose, $8-15 \mathrm{~mm}$ tall, $12-20 \mathrm{~mm}$ in diam., grayish to white. Stem red, ascending to erect, $7-22 \mathrm{~cm}$ tall, villous with 8-15 leaves. Leaves alternate, lamina membranous, asymmetric, lanceolate, $2.5-12 \times 0.7-2.2 \mathrm{~cm}$, base oblique cordate or truncate, apex obtuse, margin serrate; adaxial surface green speckled with white sunken pits, glandular pubescent; abaxial surface reddish purple, glandular pubescent; venation pinnate, veins $7-10$, prominent beneath. Petioles 2-6 $\mathrm{mm}$ long, glandular pubescent, fleshy, red. Stipules red, persistent, membranous, linear, $2-4 \times$ $0.7-1 \mathrm{~mm}$, acuminate, with entire margin, outside glandular pubescent, inside glabrous. Inflorescence simple cyme or flowers axillar, solitary, unisexual, $2.8-4.5 \mathrm{~cm}$ long, protandrous. Peduncles: staminate inflorescences $12-17 \mathrm{~mm}$ long, pistillate inflorescences 8-12 mm long, both lightly green to reddish, white glandular pubescent. Bracts linear to orbicular, $2-3 \times 0.8-1.2 \mathrm{~mm}$, red, acuminate, entire along margin, glandular puberulent abaxially. Staminate flowers: pedicels light green, 8-12 $\mathrm{mm}$ long, erect or ascending, sparsely glandular pubescent; tepals 4, white, glabrous, outer pair broadly elliptic, 3-4 × 2.5-3 $\mathrm{mm}$, apex obtuse to rounded, inner pair narrowly elliptic, $2.5-3 \times$ 0.8-1.2 mm, apex rounded; stamens ca. 38, bright yellow, filaments clustering at base, ca. $1 \mathrm{~mm}$ long, free part ca. $0.4-0.8 \mathrm{~mm}$ long, anthers obovate to oblong, $0.5-1 \mathrm{~mm}$ long, dehiscing by longitudinal apical slits. Pistillate flowers: pedicels $8-10 \mathrm{~mm}$ long, pale green to red, glandular puberulent; tepals 5 , pale green to white, outer 2 , elliptic-obovate, $2.8-3.2 \times 1.2-1.4 \mathrm{~mm}$, apex obtuse to rounded, sparsely glandular pubescent, inner 3 subequal, narrowly obovate, $2.5-3 \times 0.8-1.2 \mathrm{~mm}$, apex rounded, glabrous; ovary light green tinged with pink, glandular pubescent, with 3 unequal wings; 3-locular, placentation axillary with one branch per locule; styles 3 , connate at the middle into common stalk, dark yellow, stigmatic band kidneyshaped, papillulose. Capsules pale green, pale brown when dry, narrowly obovoid, 6-9 × 3-4 mm; locules subglobose, $1-1.5 \times 0.8-1.2 \mathrm{~mm}$, glandular pubescent, glabrescent to glabrous when dry, dorsal wing triangular, 3-4 mm long, lateral wings $0.5-1$ $\mathrm{mm}$ wide at base. Seeds numerous, ellipsoid to globose, $0.1-0.2 \times$ ca. $0.1 \mathrm{~mm}$, testa reticulate.

Distribution. Endemic to Nam Phouy National Protected Area (Sainyabuli Province, Thongmixai District).

Ecology and phenology. Wet sandy soil in deciduous forest mixed with bamboo. Flowers in September, fruits in October.

Vernacular name. Som Koung Khao Dang (white speckled begonia).

Notes. The characteristic arrangement of leaves and glandular hairy ovary of this species are similar to $B$. namkadingensis C.-J. Yang, Souladeth et Tagane and B. pteridiformis Phutthai from B. sect. Lauchea (Moonlight et al., 2018). Meanwhile, our plant differs in having 3-lobed ovary with one branch per locule (vs. 2-lobed ovary with two branches per locule). The specific epithet refers to dorsal wing of capsule that looks like broad spine.

Proposed IUCN (2019) category. Endangered (EN B1, 2bc (i, ii, iv). Begonia heterocantha is very rare plant currently known only from the type locality with less than 15 observed plants. The known area of the species occupancy covers less than $4 \mathrm{~km}^{2}$ and extent of occupancy not more than $2 \mathrm{~km}^{2}$. Hence, we consider $B$. heterocantha as an endangered species under the IUCN criteria EN B1 and 2. 


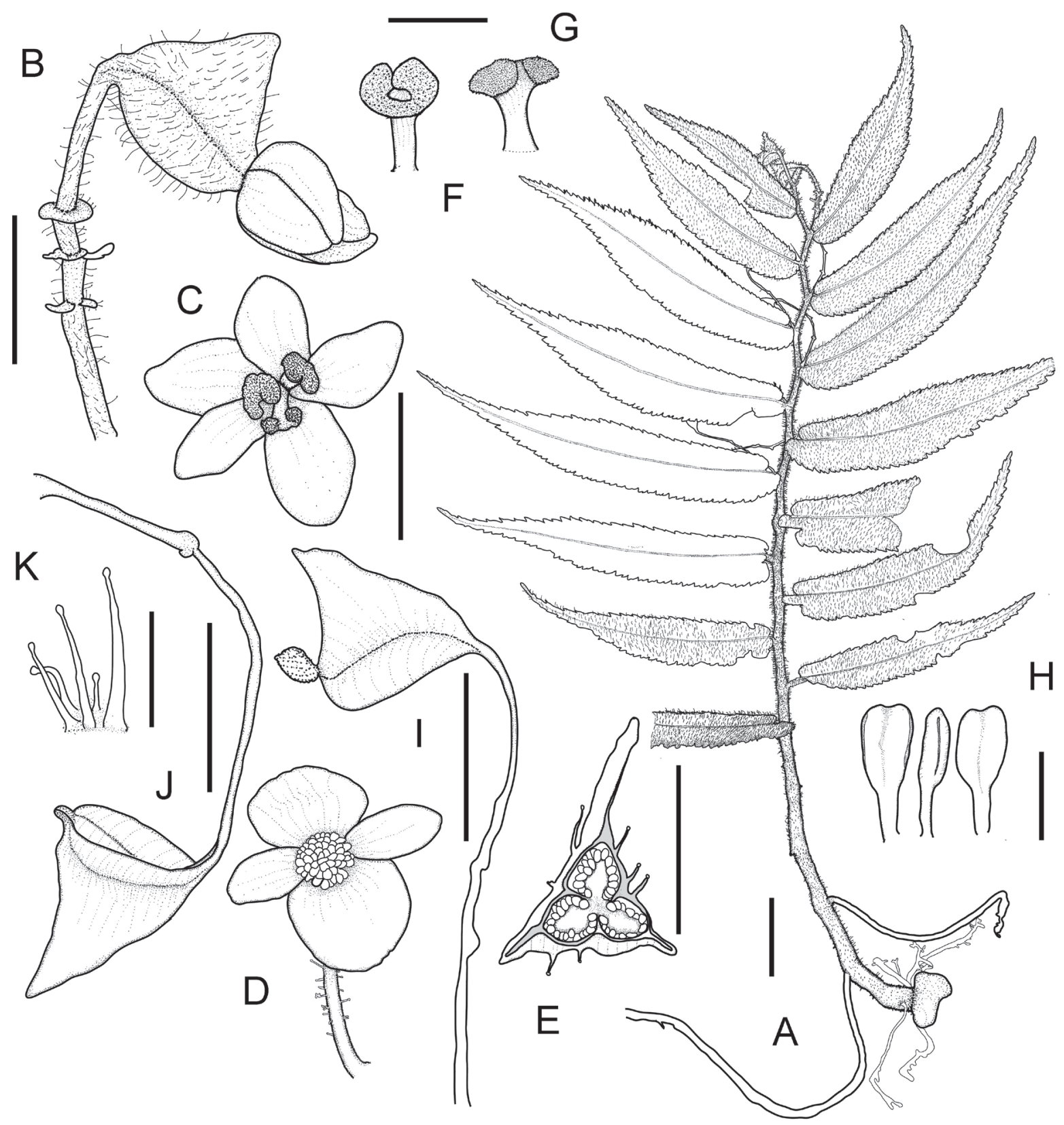

Fig. 3. Begonia heteracantha Souvann. et Lanors.: A - Flowering plant; B, C - pistillate flowers, side and frontal views; D - Staminate flower, frontal view; E - Ovary, cross section; F, G - Stigmatic band, ventral and dorsal views; $\mathrm{H}$ - Anthers, ventral, lateral and dorsal views; I, J - Capsules, side views; K - Glandular hairs. Scale bars: A-D, I, J $1 \mathrm{~cm} ; \mathrm{E}-5 \mathrm{~mm} ; \mathrm{F}-\mathrm{H}, \mathrm{K}-1 \mathrm{~mm}$. Drawn by K. Souvannakhoummane. nov.

Begonia lanxangensis Souvann. et Aver., sp.

(B. sect. Monophyllon A. DC.)

Type: "Lao PDR, Vientiane Province, Toulakhom District, Phou Khao Khouay National Protected Area, near Nam Ngeum Reservoir, $18^{\circ} 25^{\prime} 52^{\prime \prime} \mathrm{N}$, $102^{\circ} 41^{\prime} 9^{\prime \prime}$, at elevation $926 \mathrm{~m}$ a. s. 1., 10 IV 2018, Souvannakhoummane K., KS-Bio 131" (HNL!, iso - QBG!).

Diagnosis. This species is closest to B. paleacea Kurz in having inflorescences arising from the base of the leaves, but it differs in having elongate tubers (vs. tubers globose), ovate-lanceolate, obscurely asymmetrical to symmetrical leaves (vs. leaves distinctly asymmetrical, ovate to orbiculate), and glabrous pedicels (vs. pedicels glandular pubescent) (Fig. 2C, 4).

Description. Monoecious tuberiferous herb $2-15 \mathrm{~cm}$ tall. Tubers elongate, $0.5-2 \mathrm{~cm}$ long, $0.2-0.5 \mathrm{~mm}$ in diameter, dark gray with many fibrous roots. Leaves solitary raising from tuber, lamina membranous, obscurely asymmetrical to 
symmetrical, narrowly ovate, $2-10 \times 0.5-5.5 \mathrm{~cm}$, cordate to truncate at base, apex obtuse, margin biserrate; densely hairy with multicellular hairs on both surfaces; adaxial surface green or green with dark brown patches along veins; abaxial surface pale green; venation palmate with 7-8 main veins, prominent beneath. Petioles $0.5-3.5$ $\mathrm{mm}$ long, pale reddish, fleshy, with multicellular hairs. Stipules persistent, membranous, narrowly lanceolate triangular, $2-3 \times 0.5-1 \mathrm{~mm}$, acuminate, margin ciliate, abaxial surface with multicellular hairs, adaxial surface glabrous, both light green. Inflorescence compound cyme arising from the base of leaves branched 1-3 times, bisexual, $0.5-12 \mathrm{~cm}$ long, staminate flowers distal and pistillate flowers basal, protandrous. Peduncles $0.5-10 \mathrm{~cm}$ long, reddish, terete, sparely puberulent with multicellular hairs, glabrous near apex. Bracts narrowly lanceolate to triangular, $2-3 \times 0.5-2.5 \mathrm{~mm}$, acuminate, margin serrate and ciliate, puberulent with multicellular hairs abaxially, pale green. Staminate flowers: pedicels $2-2.8 \mathrm{~mm}$ long, green, erect, glabrous; tepals 4 , white to pink, outer pair elliptic to orbicular, 3-3.6 $\times 4-4.2 \mathrm{~mm}$, apex obtuse to rounded, abaxial surface sparsely puberulent to glabrescent, adaxial surface glabrous, inner pair narrowly elliptic,

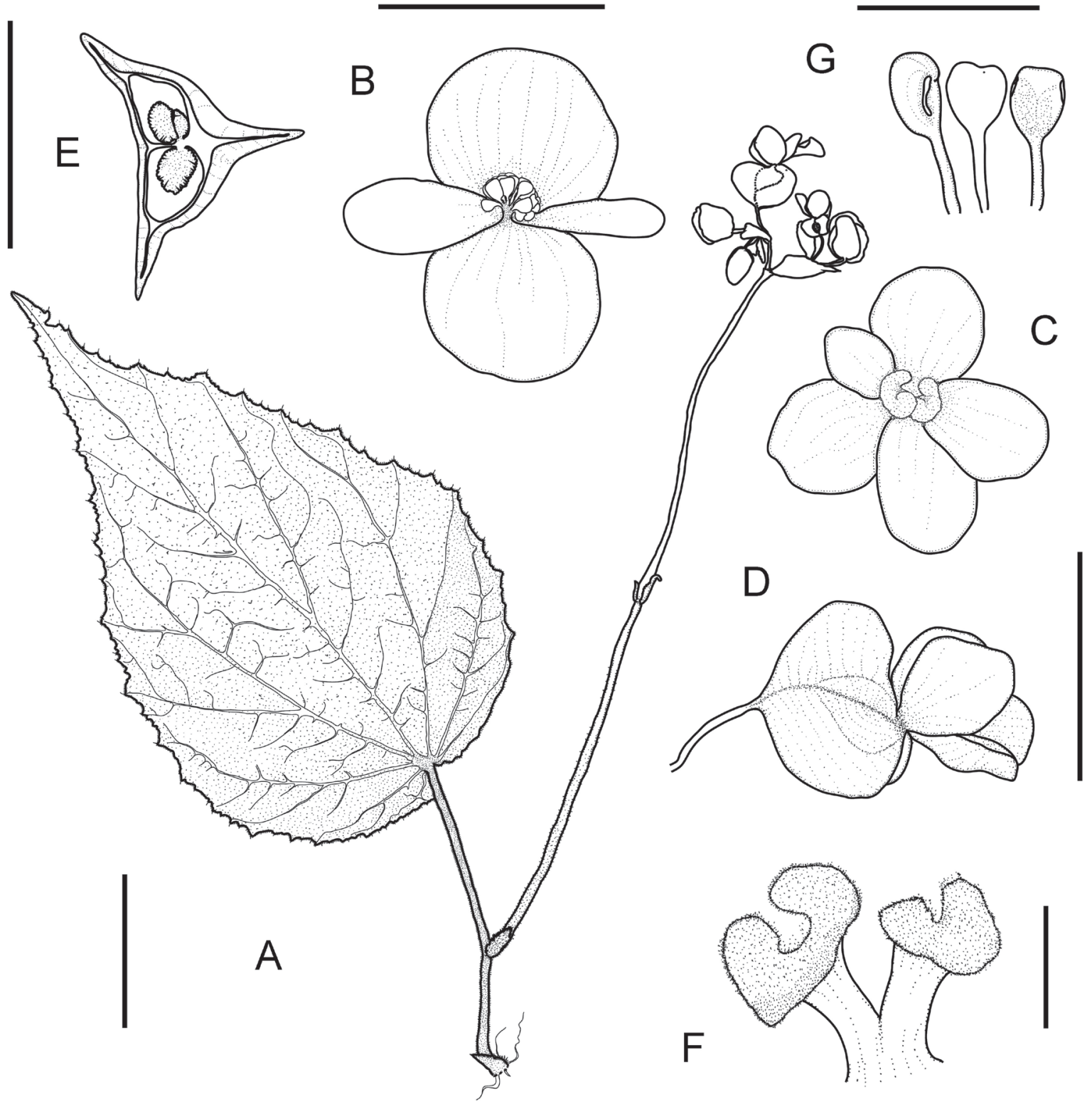

Fig. 4. Begonia lanxangensis Souvann. et Aver.: A - Flowering plant; B - staminate flower, frontal view; C, D Pistillate flowers, frontal and side views; E - Ovary, cross section; F - Style and stigmatic bands; G - Anthers, lateral, dorsal and ventral views. Scale bars: A $-2 \mathrm{~cm}$; B-F $-1 \mathrm{~cm} ; \mathrm{G}, \mathrm{H}-1 \mathrm{~mm}$. Drawn by K. Souvannakhoummane. 
$3.5-4.0 \times 1-1.5 \mathrm{~mm}$, rounded at apex, glabrous; stamens ca. 27 , bright yellow, filament $0.6-1 \mathrm{~mm}$ long, free part $0.3-0.5 \mathrm{~mm}$ long, anthers obovate, $0.2-0.3 \mathrm{~mm}$ long, dehiscing by longitudinal apical slits. Pistillate flowers: pedicels $2-3 \mathrm{~mm}$ long, light green, glabrous; tepals 5 , white, glabrous, 4 subequal, broadly elliptic, $2.7-3 \times 2.0-2.2 \mathrm{~mm}$, apex obtuse to rounded; ovary light green, glabrous, with 3 equal wings, 2-locular; placentation axillary, with one or two branches per locule; styles 2, connate at the middle into common stalk, dark yellow, stigmatic band U-shaped, papillulose. Fruits unknown.

Distribution. Known only from type locality at Phou Khao Khouay National Protected Area (Vientiane Province).

Ecology and phenology. Moist mossy rocks in seasonally dry evergreen forest mixed with bamboo on the hill slopes. Flowers in May - June.

Vernacular name. Som Koung Lane Xang (million elephant begonia).

Notes. This species is similar to B. poilanei Kiew (B. sect. Diploclinium) in elongate tubers and dark color patches along veins on the adaxial leaf surface. The leaves of $B$. lanxangensis are narrowly ovate, inflorescences arise from the base of the leaf, two stigmas, ovaries with two locules; in the opposition, B. poilanei has broadly ovate leaves, inflorescences arising from the tuber, three stigmas, and ovaries with three locules (Kiew, 2007). The species epithet refers the old name of Lao PDR, which means "Kingdom of million elephants", as well as Phou Khao Khouay National Protected Area is one of a few elephant habitats still existing in the country.

Proposed IUCN (2019) category. Begonia lanxangensis is currently only known from the type locality situated in Phou Khao Khouay National Protect Area. Local people use the area of species location for recreation and pasturing that seriously disturbs the alone known population. Thus, the species is estimated as becoming Critically Endangered in the near further. Hence, we consider a category of VU D2 to be appropriate for this species.

Begonia parviglandulosa Souvann. et Lanors., sp. nov.

(B. sect. Parvibegonia A. DC.)

Type: "Lao PDR, Vientiane Province, Thoulakhom District, Phou Khao Khouay National Protected Area, Tad Xang Waterfall, $18^{\circ} 22^{\prime} 07.5^{\prime \prime} \mathrm{N}, 102^{\circ} 42^{\prime} 09.3^{\prime \prime} \mathrm{E}$, at elevation $250 \mathrm{~m}$ a. s. 1., 4 X 2019, Lanorsavanh S., Vongphachan S.,
Souvannakhoummane S., SL 1746" (HNL!, iso FOF!, KKU!, QBG!).

Diagnosis. The plant is most similar to $B$. martabanica A. DC. but differs in smaller habitus, reniform-cordate leaves (vs. leaves ovate), peduncle, pedicle and capsules with glandular hairs (vs. pubescent with simple hairs) (Fig. 2D, 5).

Description. Monoecious tuberiferous herb, $4.5-7 \mathrm{~cm}$ tall. Tubers oblate or globose, $2-4 \mathrm{~mm}$ long, 2.5-3.6 $\mathrm{mm}$ in diameter, light gray. Stem green near the base, in upper part reddish, erect, $2-4 \mathrm{~cm}$ tall, sparsely glandular pubescent, with 2-4 leaves. Leaves alternate, lamina membranous, symmetrical, reniform-cordate, $1.2-2.6 \times 1.4-3.2$ $\mathrm{cm}$, base cordate to truncate, apex obtuse, margin biserrate; adaxial surface green; abaxial surface pale green; puberulent on both surfaces; venation palmate, veins ca. 5, prominent beneath. Petioles 5-12 mm long, pale green to red, fleshy, puberulent to glabrescent. Stipules light green, persistent, membranous, narrowly triangular lanceolate, $1.2-1.8 \times 0.3-0.6 \mathrm{~mm}$, apex acuminate, margin entire, adaxial surface glabrous, abaxial surface puberulent. Inflorescences compound cyme arising from the apical part of stem, branched, bisexual, $2.5-3.5 \mathrm{~cm}$ long, staminate flowers distal, pistillate flowers basal, protandrous. Peduncles $2-3 \mathrm{~cm}$ long, light green to reddish, terete, glandular pubescent. Bracts narrowly lanceolate to triangular, 2-3 $\times$ 0.8-1.2 mm, apex acuminate, margin entire, puberulent abaxially, pale green. Staminate flowers: pedicels $2-3 \mathrm{~mm}$ long, green, erect or occasionally ascending, with sparse glandular hairs; tepals 4, white; outer pair elliptic, 3-3.2 $\times 2-2.5 \mathrm{~mm}$, obtuse to rounded, sparsely puberulent to glabrescent outside, glabrous inside; inner pair narrowly elliptic, 2-2.5 $\times$ 0.4-0.8 mm, apex rounded, glabrous; stamens ca. 18 , bright yellow, filaments ca. $1.5 \mathrm{~mm}$ long, free part ca. $0.4 \mathrm{~mm}$ long, anthers obovate, $0.2-0.5 \mathrm{~mm}$ long, dehiscing by longitudinal apical slits. Pistillate flowers: pedicels $5-12 \mathrm{~mm}$ long, light green, glandular puberulent, with minute linear bract near apex, 2-2.5 mm long, puberulent; tepals 5 , white; outer 2 , broadly obovate, $2.8-3.4 \times 1.2-1.4$ $\mathrm{mm}$, apex obtuse to rounded, puberulent outside; inner 3 subequal, narrowly obovate, $2.7-3.2 \times 0.7-1$ $\mathrm{mm}$, apex rounded, glabrous; ovary light green with reddish or pink tint, glandular pubescent, with 3 equal wings; 2-locular; placentation axillary, with one branch per locule; styles 2, connate at the middle into common stalk, dark yellow, stigmatic band U-shaped, papillulose. Capsules pale green with red 
tint, pale brown (when dry), elliptic to subglobose, $3.8-5.7 \times 3.5-4.4 \mathrm{~mm}$; locules subglobose, $1.2-$ $1.5 \times 1-1.2 \mathrm{~mm}$, dorsal wing triangular to halforbicular, ca. $4.5 \mathrm{~mm}$ long, lateral wings $1.5-2.3 \mathrm{~mm}$ wide at base, glabrescent to glandular puberulent. Seeds numerous, brown, elliptic to globose, $0.2-$ $0.3 \times$ ca. $0.1 \mathrm{~mm}$, testa reticulate.
Distribution. Endemic of Phou Khao Khouay National Protected Area (Vientiane Province).

Ecology and phenology. Moist mossy rocks in seasonally dry evergreen forest mixed with bamboo near stream. Flowers in July - October, fruits in October - November.

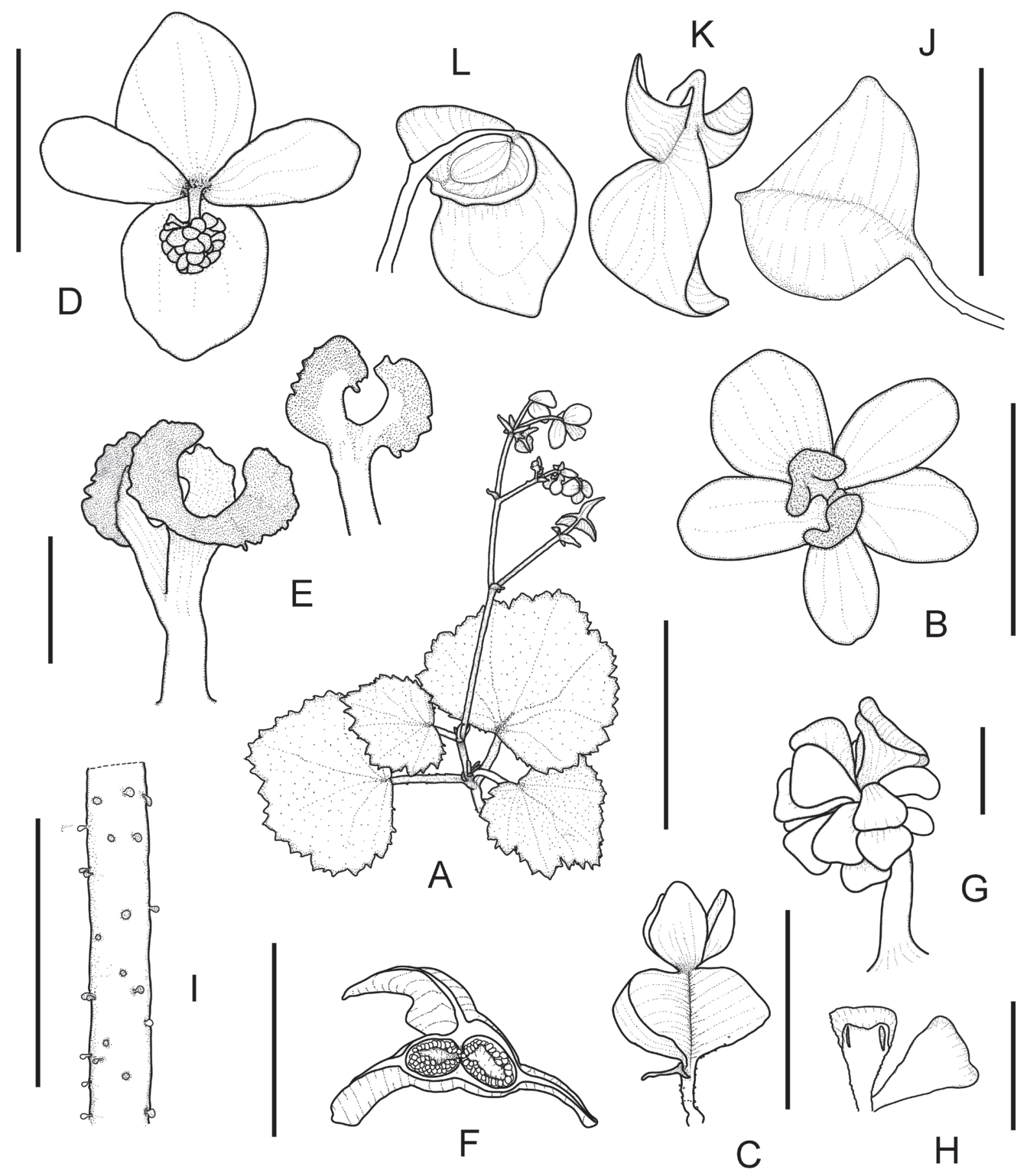

Fig. 5. Begonia parviglandulosa Souvann. et Lanors.: A - Flowering plant; B, C - Pistillate flowers, frontal and side views; D - Staminate flowers, frontal view; E - Style and stigmatic bands, ventral and dorsal views; F - Ripe capsule, cross section; $\mathrm{G}$ - Stamens; H - Anthers, frontal and dorsal views; I - Glands on peduncle; J-L - Capsules, views from different sides. Scale bars: A $-3 \mathrm{~cm}$; B-D, F, J-L -5 mm; E, G, H $-1 \mathrm{~mm}$; I -2 mm. Drawn by K. Souvannakhoummane. 
Vernacular name. Som Koung Noi (weed begonia).

Notes. This species has smaller habitus in comparison with similar B. hymenphylla Gagnep. (B. sect. Reichenheimia) but differs in having ovary of 2-lobes (vs. ovary with 3 lobes), 2 styles (vs. 3 styles), and sparely glandular puberulent stem (vs. stem glabrous). The specific epithet refers characteristic glandular indumentum.

Proposed IUCN (2019) category. Endangered (EN B1ab(i, ii, v)). Begonia parviglandulosa is currently known from the only type locality at Tad Xang Waterfall in Phou Khao Khouay National Protected Area. This area is affected by intensive recreation by tourism and local people harvesting a lot of medicinal and edible plants, as well as firewood that seriously disturbs primary habitats. The known area of this species occupancy is ca. $4 \mathrm{~km}^{2}$. All observed individuals form less than 50 colonies. Hence, we consider B. parviglandulosa to be endangered species under the EN B1 IUCN criterion.

Additional specimens examined. The same location as holotype, 22 July 2018, Lanorsavanh S., Lamxay C., SL 1457 (KKU, QBG and alcohol preserved collection at Biology herbarium of National University of Lao PDR).

\section{Begonia pseudobrandisiana Souvann. Lanors., sp. nov. \\ (B. sect. Reichenheimia (Klotzsch) A. DC.)}

Type: "Lao PDR, Khammouane Province, Thakheak District, Tham Nang Ene Cave Preserved Area, $17^{\circ} 26^{\prime} 39.0^{\prime \prime} \mathrm{N}, 104^{\circ} 56^{\prime} 52.9^{\prime \prime} \mathrm{E}$, at elevation $200 \mathrm{~m}$ a. s. 1., 21 VII 2019, Lanorsavanh S., Souvannakhoummane K., Xayyavong K., SL 1723“ (HNL!; iso - HNL!, FOF!, KKU!, QBG!).

Diagnosis. The new species is similar to B. brandisiana Kurz but differs in pistillate flowers having five tepals (vs. pistillate flowers with two tepals), outer pairs of tepals of both staminate and pistillate flowers elliptic-oblanceolate (vs. tepals orbiculate) (Fig. 2E, 6).

Description. Monoecious tuberiferous herb, $8-15 \mathrm{~cm}$ tall. Tubers oblate to globose, $2-3 \times 1.2-$ $1.5 \mathrm{~mm}$, grayish with many fibrous roots. Leaves 1(2), arising from tuber, lamina membranous, glabrous, symmetrical, reniform to semi-orbiculate, 10-17 $\times 10-11 \mathrm{~cm}$, base truncate, apex acute, with 5-7 broadly triangular lobes; adaxial surface dark green, yellowish-silver green along veins; abaxial surface pale green; venation palmate, veins $5-7$, prominent beneath. Petioles $8.5-11 \mathrm{~mm}$ long, reddish-green, fleshy, glabrous. Stipules not seen. Inflorescence compound cyme arising from the tuber, branched 3-6 times, bisexual, 15-27 cm long, staminate flowers distal, pistillate flowers basal, protandrous. Peduncles $5.5-8.5 \mathrm{~cm}$ long, greenreddish, terete, glabrous. Bracts linear to elliptic, $1-2 \times$ ca. $1 \mathrm{~mm}$, glabrous, pale green. Staminate flowers: pedicels 5-9 $\mathrm{mm}$ long, reddish-green, glabrous; tepals 4, glabrous, light pinkish; outer pair elliptic-oblanceolate, $3-4 \times 2-2.5 \mathrm{~mm}$, acute; inner pair narrowly elliptic-oblong, 3-3.5 $\times 0.5-1$ $\mathrm{mm}$, rounded at apex; stamens ca. 13, bright yellow, filaments free, $0.6-1.2 \mathrm{~mm}$ long, anthers ellipticoblong, $0.8-1.2 \mathrm{~mm}$ long, dehiscing by longitudinal apical slits. Pistillate flowers: pedicels $4-6 \mathrm{~cm}$ long, dark red to pink, glabrous; tepals 4-5, glabrous, white to light pink; outer pair equal, elliptic, 3.8$4.2 \times 2.5-3 \mathrm{~mm}$, apex acute to rounded; inner 3 smaller, linear to elliptic, $2-3 \times 0.8-1.2 \mathrm{~mm}$, apex rounded; ovary light pinkish, glabrous, with 3 unequal wings; dorsal wing cucullate, lateral wing half orbiculate; 3-locular; placentation axillary with one branch per locule; styles 3, connate at the base, dark yellow, stigma band kidney-shaped, papillulose. Capsule globose, glabrous, $10-12 \times 5-8$ $\mathrm{mm}$. Seeds ellipsoid, ca. $0.3 \times$ ca. $0.2 \mathrm{~mm}$, brownishyellow, reticulate.

Distribution. This species known only from Tham Nang Ene Cave Preserved Area (Khammouane Province, Thakheak District).

Ecology and phenology. Rock on limestone hills covered by deciduous forest in association with Globba sp., Zingiber sp., Impatiens sp., and Argostemma sp. Flowers in June - August, fruits in July - September.

Vernacular name. Som Koung Bai Dok Thong (butea leaf begonia).

Notes. This species is also similar to $B$. demissa Craib in having the same number of tepals in staminate and pistillate flowers but differs in lack of whorl of leaves at the base of inflorescence (vs. two-four leaved whorl at the base of inflorescences), and in reniform to semi-orbiculate leaves (vs. leaves triangular cordate). The specific epithet refers to the superficial similarity of the new species with B. brandisiana.

Proposed IUCN (2019) category. Vulnerable (VU D2). The lone known population of B. pseudobrandisiana at Tham Nang Ene tourism area includes less than 30 individual plants. The species area of occupancy is about $4 \mathrm{~km}^{2}$, and the extent of occupancy is less than $20 \mathrm{~km}^{2}$. The collecting of samples by numerous tourists as an 
ornamental plant is a serious damage factor for the survival of the species population. Hence, we consider $B$. pseudobrandisiana to be vulnerable under the VU D2 IUCN criterion.

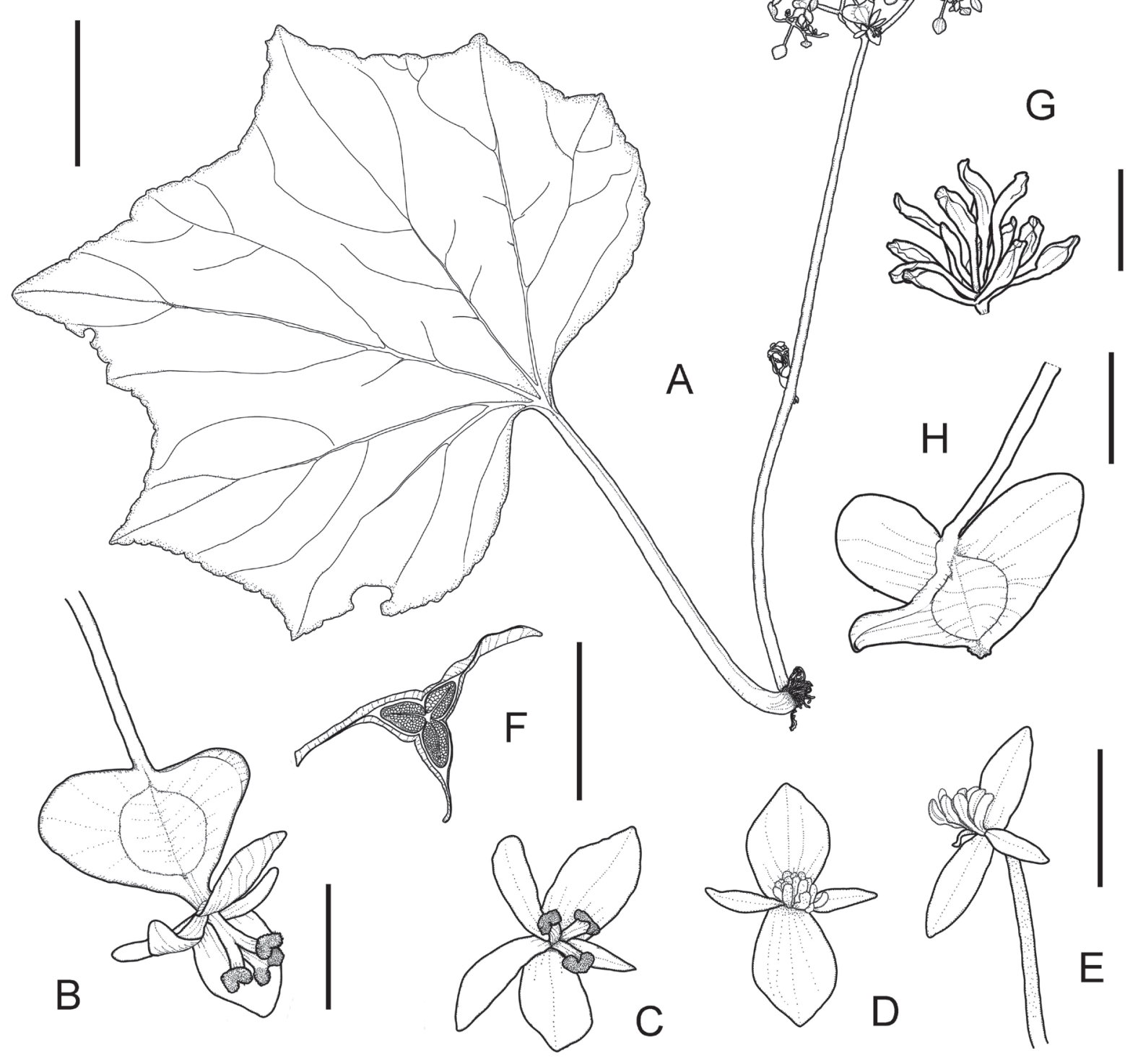

Fig. 6. Begonia pseudobrandisiana Souvann. et Lanors.: A - Flowering plant; B, C - Pistillate flowers, side and frontal views; D, E - Staminate flowers, frontal and side views; F - Ovary, cross section; G - Stamens; H - Capsule, side view. Scale bars: A $-3 \mathrm{~cm}$; B-F $-1 \mathrm{~cm} ; \mathrm{H}-5 \mathrm{~mm} ; \mathrm{G}-2 \mathrm{~mm}$. Drawn by K. Souvannakhoummane.

Begonia tripartifolia Souvann. et Lanors., sp. nov.

(B. sect. Reichenheimia (Klotzsch) A. DC.)

Type: "Lao PDR, Khammouane Province, Mahaxay District, Na Tung Village, $17^{\circ} 26^{\prime} 47.8^{\prime \prime} \mathrm{N}$, $105^{\circ} 06^{\prime} 24.6^{\prime \prime} \mathrm{E}$, at elevation $174 \mathrm{~m}$ a. s. 1., 6 VIII 2019, Lanorsavanh S., Lamxay V., Xayyavong K. SL1725" (HNL!, iso - FOF!, KKU!, QBG!).

Diagnosis. The species is similarto $B$. tricuspidata C. B. Clarke from B. sect. Alicida C. B. Clarke but differs in having leaves palmate triangular-ovate, with deeply lobed lacerate margin (vs. leaves ovate with almost entire or crenate margin), pistillate flower with five tepals (vs. pistillate flowers with four tepals), ovary with unequal wings, dorsal wing smaller, triangular, lateral wings broadly lunate (vs. ovary with subequal wings) (Fig. 2F, 7).

Description. Monoecious tuberiferous herb, $5-10 \mathrm{~cm}$ tall. Tubers globose, $1-2 \times 0.5-0.8 \mathrm{~cm}$, light yellowish, with many fibrous roots. Stem erect, 
succulent, up to $8 \mathrm{~cm}$ long, reddish, glabrous or glandular hairy. One leaf solitary arising from tuber; floriferous stem at middle bears whorl of 3-5 cauline leaves; leaf lamina membranous, symmetrical, palmate triangular-ovate in outline, $2-4.5 \times 1.5-3$ $\mathrm{cm}$, at base truncate-cuneate, apex acute, margin deeply lobed, tripartite or lacerate; adaxial surface puberulent, dark green; abaxial surface glabrescent, reddish; venation palmate, veins $3-5$, prominent beneath. Petiole 5-25 cm long, red, succulent, puberulent. Stipules persistent, membranous, light reddish, narrowly triangular, $1-1.5 \times 0.4-0.5 \mathrm{~mm}$, acuminate, margin entire, adaxially glabrous, abaxially puberulent. Inflorescence compound cyme arising from the apical part of stem, branched 1-3 times, bisexual, 3-5 cm long; staminate flowers distal, pistillate flowers basal, protandrous. Peduncles $2-4 \mathrm{~cm}$ long, green or reddish, terete, glabrous. Bracts linear, reddish, $1-2 \times 0.2-0.3 \mathrm{~mm}$, shortly attenuate, margin entire. Staminate flowers:

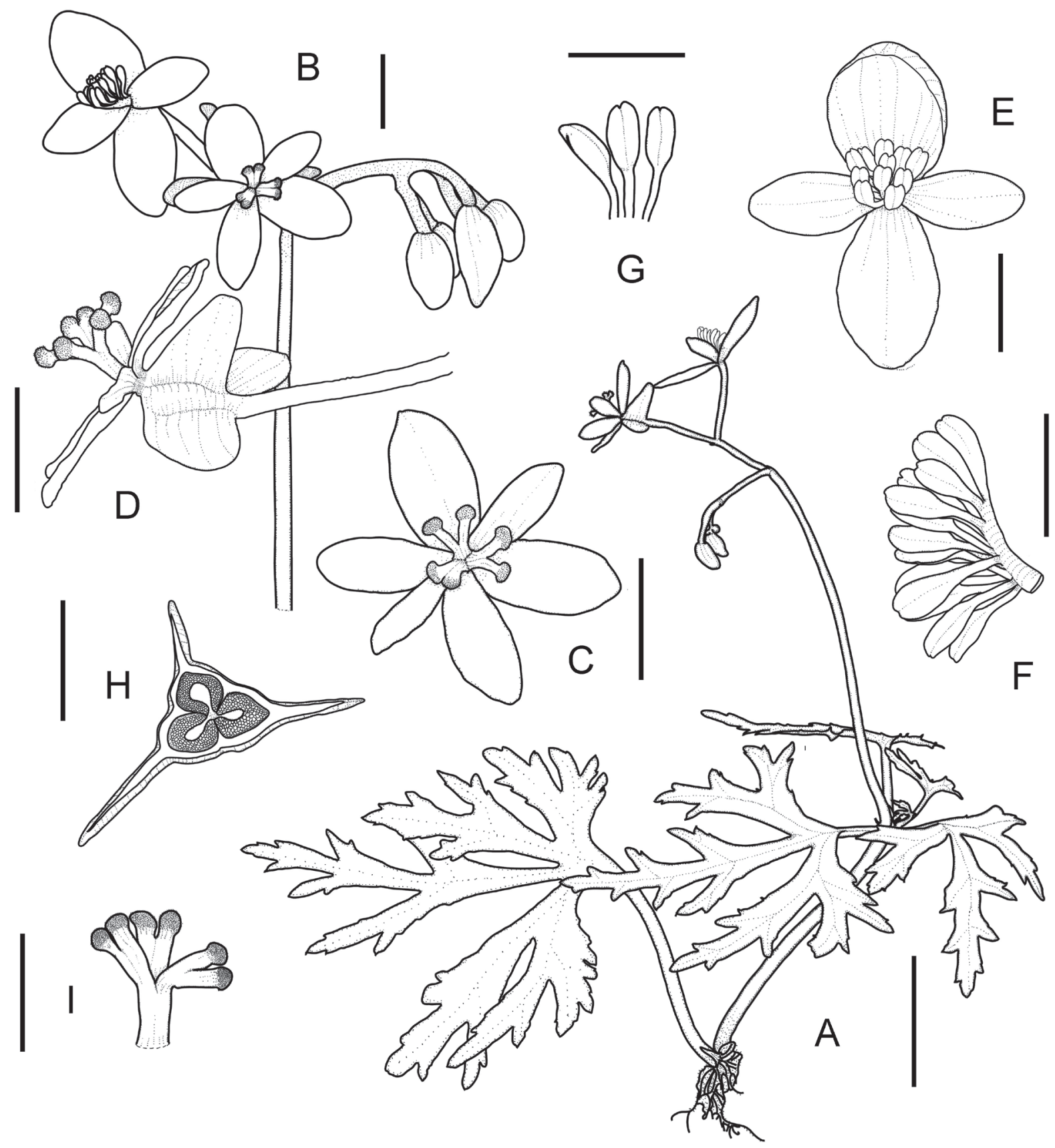

Fig. 7. Begonia tripartifolia Souvann. et Lanors.: A - Flowering plant; B - Inflorescence; C, D - Pistillate flowers, frontal and side views; E - Staminate flowers, frontal view; F - Stamens; G - Anthers ventral, lateral and dorsal views; $\mathrm{H}$ - Ovary, cross section; I - Style and stigmatic bands, side view. Scale bars: A - $2 \mathrm{~cm}$; B-E - $5 \mathrm{~mm}$; E, F-I - 2 mm. Drawn by K. Souvannakhoummane. 
pedicels $3-6 \mathrm{~mm}$ long, pale green to pale reddish, glandular hairy; tepals 4 , light pinkish; outer pair elliptic, $5-7 \times 2.5-3 \mathrm{~mm}$, apex rounded, adaxially glabrous, abaxially glandular hairy; inner pair narrowly elliptic-oblong, glabrous, 3.5-4 × $0.7-1$ $\mathrm{mm}$, apex rounded; stamens ca. 13 , bright yellow, filaments connected on 1.2-2 $\mathrm{mm}$ long, free part 0.4-0.6 mm long, anthers elliptic-oblong, $1-1.2 \mathrm{~mm}$ long, dehiscing by longitudinal apical slits. Pistillate flowers: pedicels $5-5.5 \mathrm{~mm}$ long, pale green to reddish, glandular hairy; tepals 5-6, white, glabrous; 4 outer subequal, broadly elliptic, $3.5-4.5 \times 1.5-2$ $\mathrm{mm}$, apex rounded; inner 2 , smaller, linear, ca. $3 \times$ $1.5 \mathrm{~mm}$, apex rounded; ovary green, glabrous, with 3 unequal wings; dorsal wing smaller, triangular; lateral wings lunate; 3-locular; placentation axillary with one branch per locule; styles 3 , connate from the middle into common stalk, dark yellow, stigmatic band Y-shaped, papillulose. Capsule globular, 4-6× 5-7 mm (including wings), green, glandular hairy. Seeds globose, brown, reticulate, $0.3-0.2 \mathrm{~mm}$ in diameter.

Distribution. Endemic of Mahaxay Karst Area (Khammouane Province, Mahaxay District).

Ecology and phenology. Limestone rocks on wet slopes in open forest or scrub in association with Microchirita sp., Argostemma sp., and Adiantum sp.

Vernacular name. Som Koung Bai Seak (deeply lobe-leaved begonia).

Notes. In its habitus, new species is similar to $B$. demissa Craib from $B$. sect. Diploclinium but differs in palmate triangular, deeply lobed, lacerate leaves, (vs. leaves triangular with biserrate margin), and triangular dorsal wing of ovary (vs. dorsal ovary wing cucullate). The specific epithet means deeply lobed, mainly tripartite leaves.

Proposed IUCN (2019) category. Endangered (EN B2). Begonia tripartifolia is known only from the type locality in Khammoune Province. The known species area of occupancy is $4 \mathrm{~km}^{2}$, and the extent of occupancy is $820 \mathrm{~km}^{2}$. Mining and cement factory activity in this area are the main factors of habitat lost. Hence, we consider B. tripartifolia to be endangered species under the EN B2 IUCN criterion.

Additional specimens examined. "Lao PDR, Khammouane Province, Boualapha District, Hin Nam No National Protected Area, $17^{\circ} 26^{\prime} 03.0^{\prime \prime} \mathrm{N}$, $105^{\circ} 46^{\prime} 31.7^{\prime \prime} \mathrm{E}$, at elevation $280 \mathrm{~m}$ a. s. 1., 8 X 2017, Lamxay V., Lanorsavanh S., Souvannakhoummane K., Vongphachan S., Keopunya T., HNN 149" (FOF and Biology Herbarium of National University of Laos).
Begonia viriditenebris Lanors. et Souvann., sp. nov.

(B. sect. Parvibegonia A. DC.)

Type: "Lao PDR, Khammouane Province, Thakheak District, Tham Nang Ene Cave Preserved Area, $17^{\circ} 26^{\prime} 39.0^{\prime \prime} \mathrm{N}, 104^{\circ} 56^{\prime} 52.9^{\prime \prime} \mathrm{E}$, at elevation 200 m a. s. 1., 4 VIII 2019, Lanorsavanh S., Lamxay V., Xayyavong K., SL 1724" (HNL!, iso - FOF!, KKU!, QBG!).

Diagnosis. This new species is similar to B. sinuata Wall. ex Meisn. but differs in single leaf, indumentum of bristle hairs and reddish or bronzy green adaxial leaf surface (vs. two-three leaves, indumentum of stellate hairs and dark green adaxial surface of leaf), three styles (vs. two styles), and glandular hairy pedicels (vs. pedicels with stellate hairs) (Fig. 8, 9A).

Description. Monoecious tuberiferous herb, $10-25 \mathrm{~cm}$ tall. Tubers oblong to moniliform, 2$3 \times 0.2-0.5 \mathrm{~cm}$, light yellowish with many fibrous roots. Leaves solitary arising from tuber, lamina membranous, symmetrical, ovate-cordate, 5-10 $\times$ 5-10 cm, at base cordate to truncate, apex acute, margin biserrate; adaxial surface smoothly bullate, dark green or bronzy green; abaxial surface pale purple; sparsely bristle hairy on both surfaces; venation palmate, veins $6-8$, prominent beneath. Petioles 1.5-4.5 mm long, green, fleshy, with bristle hairs. Stipules persistent, membranous, light green, narrowly lanceolate triangular, $2-2.5 \times 0.4-1 \mathrm{~mm}$, apex acuminate, margin dentate, adaxially glabrous, abaxially puberulent. Inflorescence compound cyme arising from the tuber, branched 2-5 times, bisexual, 8-22 cm long; staminate flowers distal, pistillate flowers basal, protandrous. Peduncles $7.5-12 \mathrm{~cm}$ long, green to reddish, terete, sparsely glandular puberulent. Bracts sub-orbiculate, 6-9 × 7-12 mm, margin entire, ciliate near apex, puberulent on abaxial surface, pale pink to red. Staminate flowers: pedicels 6-12 $\mathrm{mm}$ long, pale green to red, glandular hairy; tepals 4, light pinkish, glabrous; outer pair obovate-orbiculate, $3-3.5 \times 5.5-6 \mathrm{~mm}$, apex rounded; inner pair narrowly elliptic-oblong, 3$4 \times 0.8-1 \mathrm{~mm}$, apex rounded; stamens $18-23$, bright yellow, filaments free, clustering, 0.4-1.2 mm long, anthers elliptic-oblong, $1.8-2 \mathrm{~mm}$ long, dehiscing by longitudinal apical slits. Pistillate flowers: pedicels 1.5-2 cm long, pink to dark red, glandular hairy; tepals 6 , light pinkish, glabrous; 4 outer subequal, obovate-oblanceolate, $10-15 \times 6-8 \mathrm{~mm}$, apex acute to rounded; inner pair smaller, linear, ca. $16 \times 2$ $\mathrm{mm}$, apex rounded; ovary light pinkish, glabrous, with 3 unequal wings; dorsal wing larger, lunate- 
triangular; 2-locular; placentation axillary with two branch per locule; styles 3 , connate from the middle into common stalk, dark yellow, stigmatic band U-shaped, papillulose. Capsules ellipsoid, ca.
$6 \times 5 \mathrm{~mm}$ (including wing), glabrous, green when young. Seeds sub-globose, yellowish-brown, ca. $1 \mathrm{~mm}$ long.

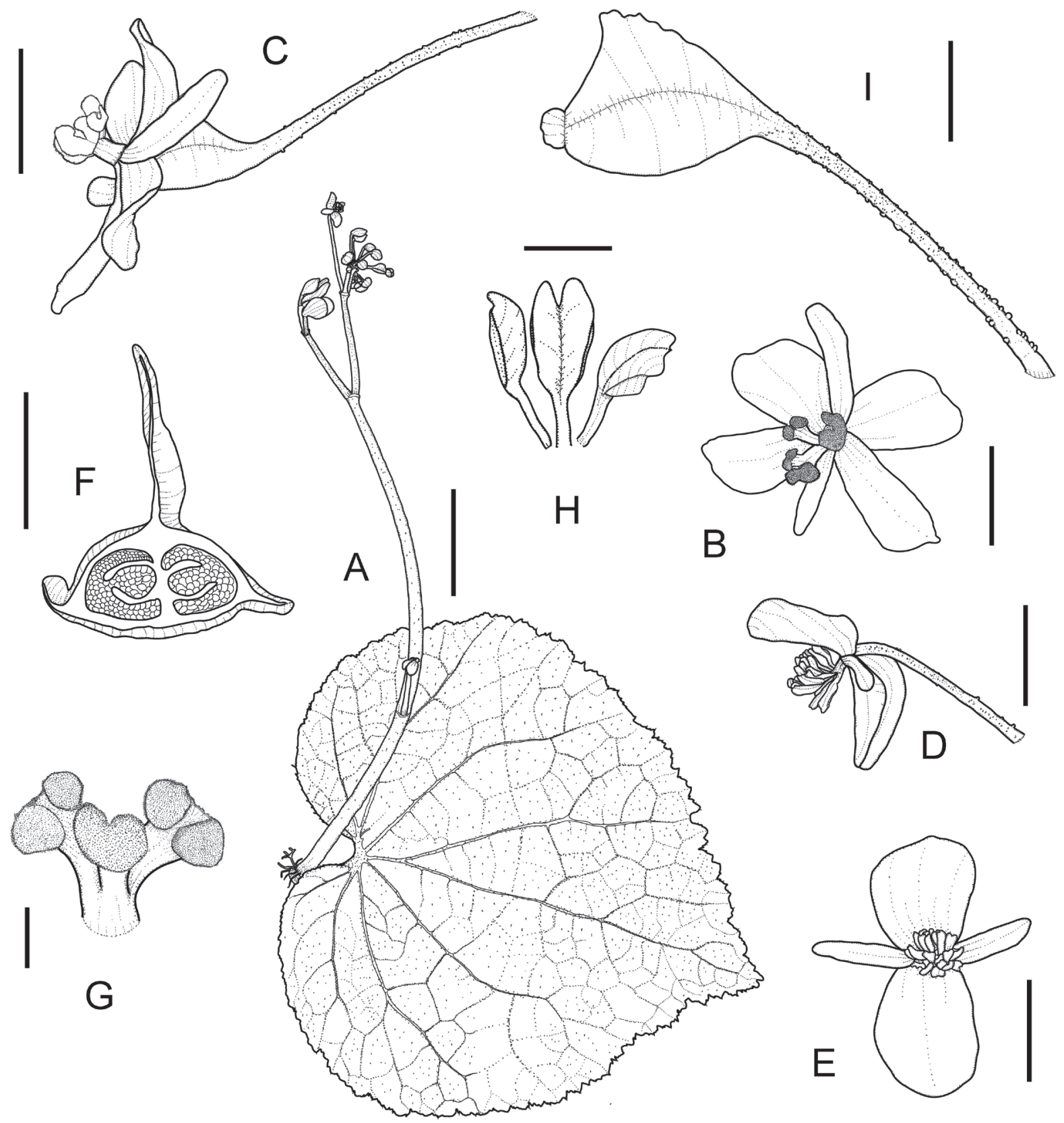

Fig. 8. Begonia viriditenebris Lanors. et Souvann.: A - Flowering plant; B, C - Pistillate flowers, frontal and side views; D, E - Staminate flowers, frontal and side views; F - Ovary, cross section; G - Style and stigmatic bands, side view; $\mathrm{H}$ - Stamens, dorsal and side views; I - Capsule, lateral view. Scale bars: A $-2 \mathrm{~cm}$; B-F, I - $5 \mathrm{~mm}$; G-H $1 \mathrm{~mm}$. Drawn by K. Souvannakhoummane.

Distribution. Endemic to Tham Nang Ene Cave area (Khammoune Province, Thakheak District).

Ecology and phenology. Wet limestone and granite rock in association with Asplenium sp., Adiantum sp., Globba sp., and Zingiber sp. Flowers in June - August, fruits in September - October.

Vernacular name. Som Koung Tham (cave begonia).

Notes. The new species resembles $B$. poilanei from Vietnam in solitary leaf and elongate tubers but 
differs in the dark or bronze-green adaxial surface of leaves (vs. leaves green with reddish blotches along veins) and 2-loculed ovary (vs. ovary 3-loculed). The specific epithet means the bronzy-green leaf color.

Proposed IUCN (2019) category. Endangered (EN B1, 2). Begonia viriditenebris is known only from the type locality at Tham Nang Ene tourism area. Its lone known population contains less than 100 individual plants. The area of occupancy is 4 $\mathrm{km}^{2}$, and the extent of occupancy is less than $20 \mathrm{~km}^{2}$. Plant collecting is the main damage factor. Hence, we consider $B$. viriditenebris to be endangered species under the EN B1 and 2 IUCN criteria.

\section{Begonia species newly recorded in the flora of Lao PDR}

Begonia hatacoa Buch.-Ham. ex D. Don (B. sect. Platycentrum (Klotzsch) A. DC.)

1825, Prodr. Fl. Nepal.: 223; Gu, Peng, Turland, 2007, Fl. China 13: 178; Camfield, Hughes, 2018, Eur. J. Taxon. 396: 43. - Type: "Nepal, Sembu, 8 VII 1802, Buchanan-Hamilton s. n." (lecto BM000521516, designated by Camfield, Hughes, 2018) (Fig. 9B).

Distribution. This species has wide distribution in mainland Asia, including India, Nepal, Sikkim, Bhutan, Myanmar, Thailand, and Vietnam (Camfield, Hughes, 2018; Hughes et al., 2018). It is also found in Phou Khao Khouay National Protected Area in Lao PDR.

Ecology and phenology. Dry evergreen and deciduous forest mixed with bamboo, along rocky stream valleys. Flowers and fruits in April - July.

Vernacular name. Som Koung Phou (mountain begonia).

Note. The species resembles $B$. caobangensis C.-I. Peng et C. W. Lin in large dorsal wings of the ovary. The leaf blade of $B$. hatacoa is ovate to lanceolate, at base cuneate to rounded, symmetric to slightly asymmetric, pistillate flowers with 4-5 tepals, in opposition the leaf lamina of $B$. caobangensis are elliptic to slightly rhomboid, attenuate and symmetric at the base, and pistillate flowers have 6 tepals.

Specimens examined. "Lao PDR, Vientiane Province, Toulakhom District, Phou Khao Khouay National Protected Area, near Nam Ngeum Reservoir, $18^{\circ} 25^{\prime} 52^{\prime \prime} \mathrm{N}, 102^{\circ} 41^{\prime} 9^{\prime \prime} \mathrm{E}$, at elevation $926 \mathrm{~m}$ a. s. 1., 10 IV 2018, Souvannakhoummane K., KS-Bio 00130" (HNL, FOF, Biology herbarium of NUoL).
Begonia hemsleyana Hook. $\mathrm{f}$.

(B. sect. Platycentrum (Klotzsch) A. DC.)

1899, Bot. Mag. 125: t. 7685; Gu, Peng, Turland, 2007, Fl. China 13: 178. - Type: "China, Yunnan, Mengtse, A. Henry 10379" (syn - K000035497, K000035498); A. Henry 55 (syn - K000035499); A. Henry 12290 (syn - GH00135181) (Fig. 9C).

Distribution. Originally described from China by Hooker (1899) and has been reported from Vietnam (Gu et al., 2007; Hughes et al., 2018). This species is known from Bolikhamxai and Champasack provinces in Lao PDR.

Ecology and phenology. Rock along stream valets in evergreen forest. Flowers in September November, fruits in December.

Vernacular name. Som Koung Bai Ngew (kapok leaf begonia).

Note. This species allies to B. jinyunensis C.-I. Peng, B. Ding et Q. Wang, but the stem of $B$. hemsleyana is erect and leaves have 7-10 leaflets, when the stem of B. jinyunensis is creeping and leaves have 4-6 leaflets. Also the species similar to B. leipingensis D. K. Tian, L. H. Yang et C. Li. and $B$. fangii Y. M. Shui et C.-I. Peng from B. sect. Coelocentrum in having compound palmate leaves but differs from them by erect stems (vs. stem creeping) and pistillate flowers having five tepals, two-cells of ovary and two styles (vs. pistillate flowers having three tepals, one-cell of ovary and three styles).

Specimens examined. "Lao PDR, Champasack Province, Paksong District, Nonglouang Village, 22 XI 2013, Phonesack S., Sengvilai L. 806" (HNL); "Bolikhamxai Province, Khamkeut District, Naheung Village, 25 XII 2018, Lanorsavanh S., Lamxay V., SL 1513" (HNL, FOF, KKU, QBG and Biology herbarium of National University of Lao PDR).

\section{Begonia labordei H. Lév.}

(B. sect. Diploclinium (Lind1.) A. DC.)

1904, Bull. Soc. Agric. Sarthe reimpr. 39: 8; Gu, Peng, Turland, 2007, Fl. China 13: 181; Ho, 1991, Ill. Fl. Vietnam 1, 2: 582; Camfield, Hughes, 2018, Eur. J. Taxon. 396: 56. - Type: "China, KouyTcheou, Montagnes des Kao-po, 11 IX 1899, J. Laborde, E. Bodinier 1952" (lecto - B100366084!, isolecto - P01900678!) (Fig. 9D).

$=B$. harrowiana Diels, 1912, Notes Roy. Bot. Gard. Edinburgh 5: 166. - Type: "China, Yunnan, Tali Valley, IX 1906, F. George 4390" (lecto E00022115!, isolecto - BM000075818!). 

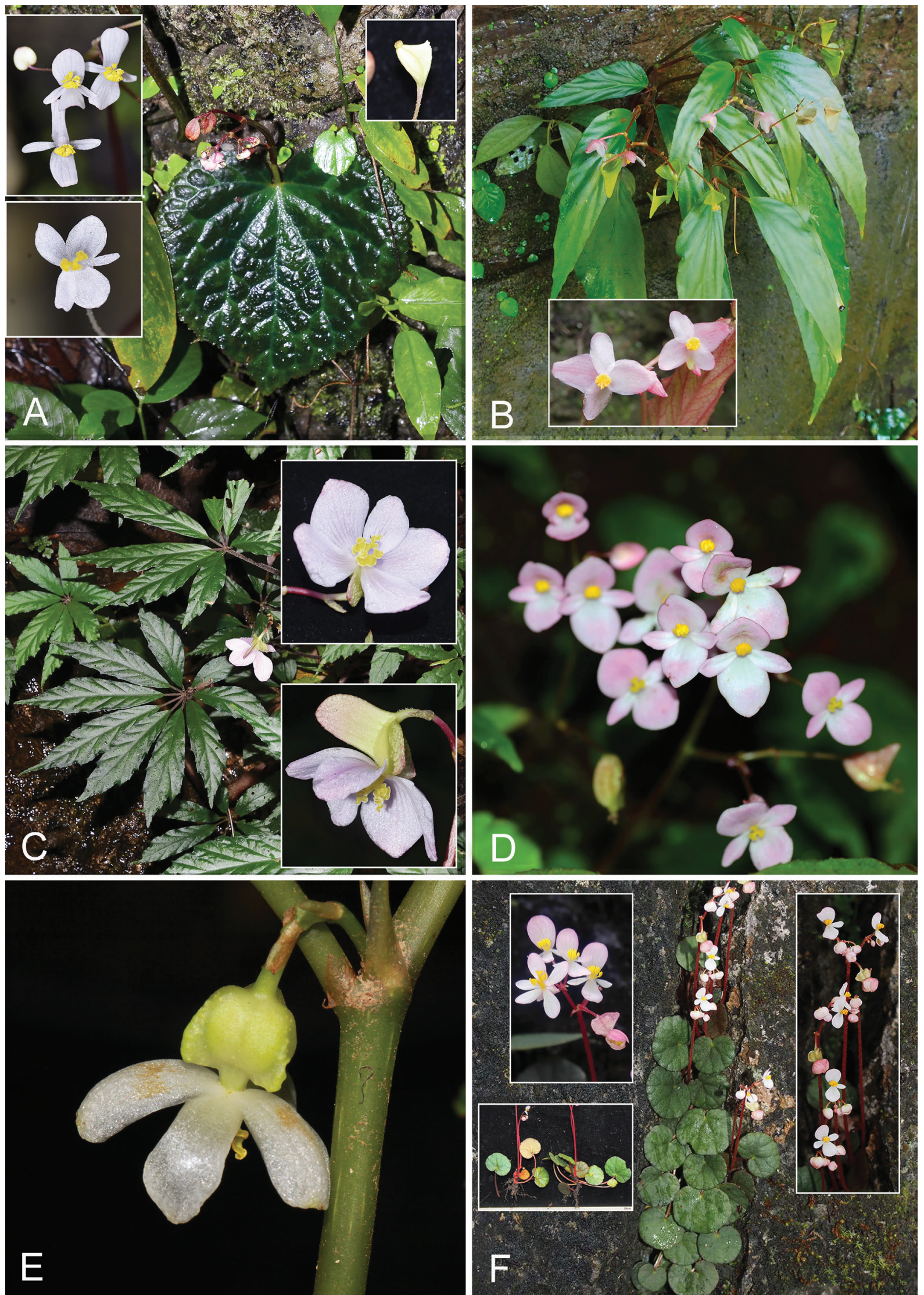

Fig. 9. Begonia viriditenebris Lanors. et Souvann.: A - Flowering plant, flowers and capsule. B. hatacoa Buch.-Ham. ex D. Don: B - Flowering plant in natural habitat and staminate flowers. B. hemsleyana Hook. f.: C - Flowering plants in natural habitat and pistillate flowers. B. labordei H. Lév.: D - Inflorescence with staminate and pistillate flowers. B. longifolia Blume: E - Pistillate flower. B. minuscula Aver.: F - Flowering plants in natural habitat, inflorescences and rhizomes. Photographs by S. Lanorsavanh (A, C-D) and K. Souvannakhoummane (B, E-F). 
= B. polyantha H. Lev. 1916, Cat. Pl. Yunnan: 17. - Type: "China, Kouy-Tcheou, J. Cavalerie s. n." (lecto - E00022111!).

Distribution. This species is known from Luang Namtha and Xiangkhouang provinces in northern part of Lao PDR. The species was originally described from China and has been reported from India, Myanmar, and Vietnam (Camfield, Hughes, 2018).

Ecology and phenology. Evergreen forests on wet sandy soil along streams. Flowers in June, fruits expectedly in August.

Vernacular name. Som Koung Nam Tha (Nam Tha begonia).

Note. Species resembles B. dioica Buch.-Ham. ex D. Don in having tubers, but the outer tepals of $B$. labordei are hairy with bristle hairs, while the outer tepals in B. dioica are glabrous.

Specimens examined. "Lao PDR, Luang Namtha Province, Sing District, Nam Ha National Protected Area, Lanorsavanh et al., NT 160 (Forest Central Research Herbarium); Xiangkhouang, Khoun District, Phou Sam Soum, 1907'25.5"N, $103^{\circ} 37^{\prime} 56.3^{\prime \prime} \mathrm{E}$, at elevation $1890 \mathrm{~m}$ a. s. 1., 9 IX 2016, Souvannakhoummane K., KS-Bio-0037" (HNL).

\section{Begonia longifolia Blume}

(B. sect. Platycentrum (Klotzsch) A. DC.)

1823, Cat. Gew. Buitenzorg: 102; Tebbitt, 2003, Brittonia 55: 25; Kiew, 2005, Begonias Penins. Malaysia: 107; Gu, Peng, Turland, 2007, Fl. China 13: 184; Girmansyah, 2008, Reinwardtia 12, 5: 428; Hughes, Girmansyah, 2011, Gard. Bull. Singapore 62, 2: 241; Camfield, Hughes, 2018, Eur. J. Taxon. 396: 58. - Type: [Indonesia] "Sumatra, Salak, Blume 740" (lecto - B100238313! designated by Camfield, Hughes, 2018) (Fig. 9E).

Distribution. This species was found in Xiangkhouang and Oudomxai provinces in northern part of Lao PDR. It was originally described from Sumatra and has been reported in mainland Asia from India, China, Myanmar, Thailand, Malaysia, and Vietnam (Kiew, 2005; Camfield, Hughes, 2018).

Ecology and phenology. Evergreen forests on wet soil along streams. Flowers in May - July, fruits in October.

Vernacular name. Som Koung Bai Yao (elongate leaf begonia).

Note. This species has many synonyms recorded by Camfield, Hughes (2018). It is very common in Lao PDR, but very few collections from Laos are available in the world herbaria.
Specimens examined. “Lao PDR, Xiangkhouang Province, Phoukoud District, Phoukoud Mountain, $19^{\circ} 33^{\prime} 32.6^{\prime \prime} \mathrm{N}, 103^{\circ} 02^{\prime} 39.9^{\prime \prime} \mathrm{E}$, at elevation $1320 \mathrm{~m}$ a. s. 1., Souvannakhoummane K. KS 226" (living plants were cultivated at Pha Tad Ke Botanical Garden); "Oudomxai Province, Xai District, Nam Veng Village, 29 IX 2012, Khantheo S., Phonesavanh X. OX 0634" (HNL0004453).

\section{Begonia minuscula Aver.}

(B. sect. Jackia M. Hughes)

2012, Turczaninowia 15, 2: 14. - Type: "Vietnam, Quang Tri Province, Huong Hoa District, Huong Viet Municipality, at elevation $600-700 \mathrm{~m}$ a. s. 1., 7 V 2011, Averyanov et al. 2838" (LE 01049401!, iso - LE 01049366!, LE 01049441!) (Fig. 9F).

Distribution. Known in Lao PDR only form Khammouane Province. This species was originally described from central Vietnam by Averyanov (Averyanov, Nguyen, 2012).

Ecology and phenology. Humid limestone clefts in deciduous forest. Flowers in August - October, fruits in November.

Vernacular name. Som Seang Deang or Som Koung Noi (small begonia).

Note. The species protologue did not contain the description of staminate flowers (Averyanov, Nguyen, 2012). In our material staminate flowers have 4 tepals, outer tepals are pubescent on the abaxial surface; the number of stamens is ca. 19 . The placentae of the ovaries are usually bilamellate.

Specimens examined. "Lao PDR, Khammouane Province, Boualapha District, Him Nam No National Protected Area, $17^{\circ} 26^{\prime} 28.0^{\prime \prime} \mathrm{N}, 105^{\circ} 46^{\prime} 21.1^{\prime \prime} \mathrm{E}$, at elevation $300 \mathrm{~m}$ a. s. 1., 11 X 2017, Lamxay V., Lanorsavanh S., Souvannakhoummmane K., Vongphachan S., Keopunya T., HNN 145" (HNL); ibidem, "12 X 2017, Lamxay V., Lanorsavanh S., Souvannakhoummmane K., Vongphachan S., Keopunya T., HNN 204" (FOF and Biology Herbarium of National University of Laos).

\section{Begonia parvula H. Lév. et Vaniot}

(B. sect. Reichenheimia (Klotzsch) A. DC.)

1906, Repert. Spec. Nov. Regni Veg. 2: 113; Gu, Peng, Turland, 2007, Fl. China 13: 190. - Type: "China, Kouy-Tcheou, X 1904, J. H. Esquirol 146" (B100366071!) (Fig. 10A).

Distribution. This species originally described from southern China (Léveillé, 1906) is known in Laos only from Louangphrabang Province. Until now, it was reported only from China and Lao PDR. 

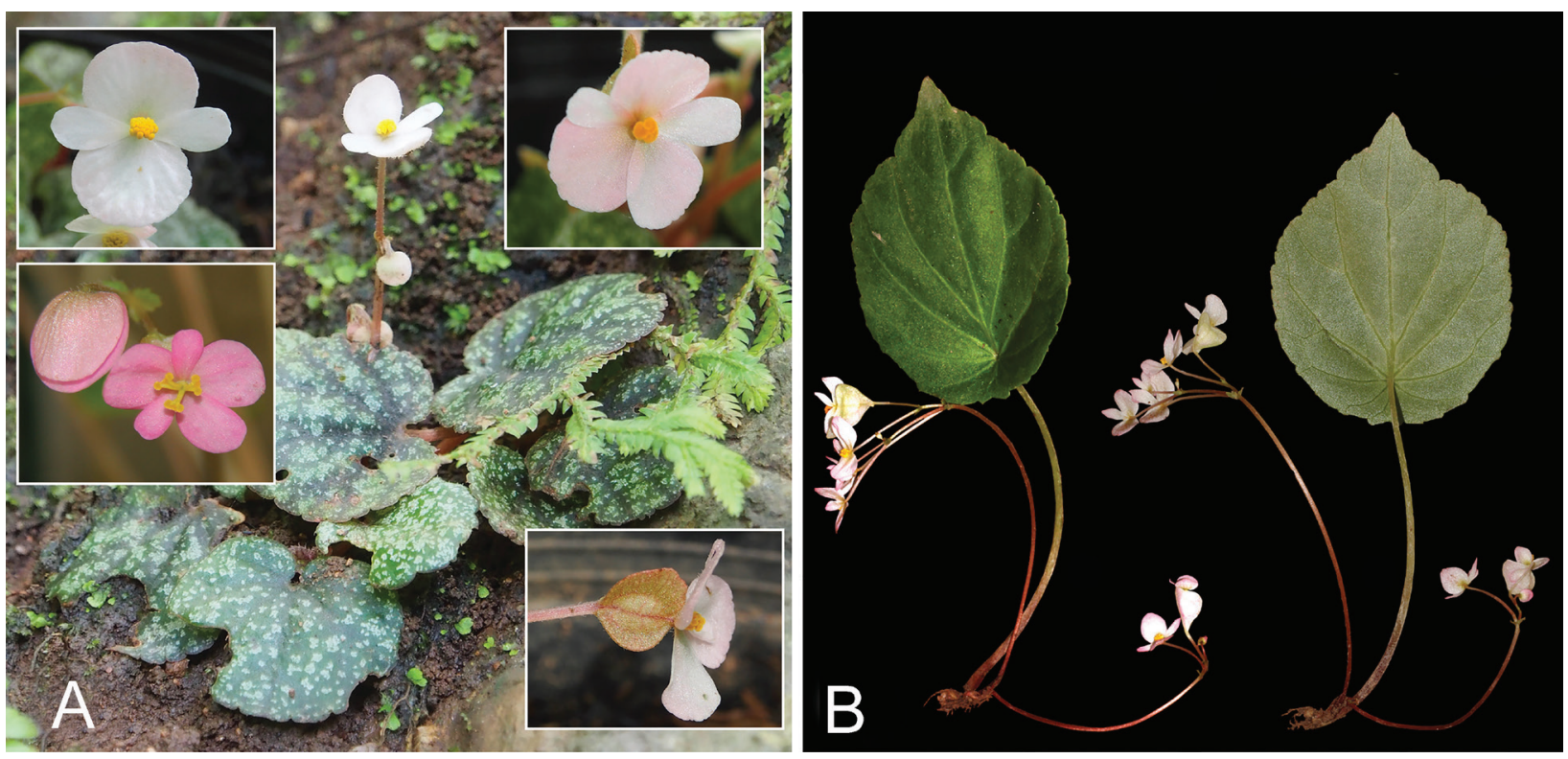

Fig. 10. Begonia parvula H. Lév. et Vaniot: A - Flowering plant in natural habitat and flowers. B. subperfoliata Parish ex Kurz: B - Flattened flowering plants. Photographs K. Souvannakhoummane.

Ecology and phenology. Humid places on sandy or clay soil mixed with rocks at foothills of limestone hills in of dry evergreen forest in Mekong River valley. Flowers in August - October, fruits in November.

Vernacular name. Som Koung Houa (tuberous begonia).

Note. This species is similar to B. henryi Hemsl. in its ephemeroid habitus, tubers, and broadly ovate, glabrous ovary. Meanwhile, the staminate and pistillate flowers of $B$. parvula have four and five tepals respectively, while both staminate and pistillate flowers of $B$. henryi have two tepals.

Specimens examined. "Lao PDR, Louangphrabang Province, Pha Nam Yard Hill, near Mekong River, 1951'04.1"N, $102^{\circ} 01^{\prime} 47.5^{\prime \prime E}$, at elevation $200 \mathrm{~m}$ a. s. $1 ., 29 \mathrm{X}$ 2012, Souvannakhoummane K., Phoutthavong K., KS 494" (QBG, alcohol-preserved specimen and living plants in Pha Tad Ke Botanical Garden); "Xiangkhoung Province, Kham District, Tham Piu Cave Area, 1940'28.9"N, 103³4'07.1"E, at elevation 700 m a. s. 1., 10 VII 2019, KS-Bio 135" (HNL).

Begonia subperfoliata Parish ex Kurz

(B. sect. Diploclinium (Lindl.) A. DC.)

1873, J. Asiat. Soc. Bengal, Pt. 2, Nat. Hist. 42, 2: 81; Clarke, 1879, Fl. Brit. India 2: 643; id. 1879, J. Linn. Soc., Bot. 18: 122; Yang et al. 2015, Plant Diversity and Resources 37, 4: 427. - Type:
[Myammar] "Moulmein, 1862, G. S. P. Parish 6" (syn - K000761421); G. S. P. Parish s. n. (syn GH00068311, isosyn - P01900777) (Fig. 10B).

Distribution. This species originally described from Myanmar (Kurz, 1873) and also reported from Thailand and Yunnan (Hughes et al., 2018; Yang et al., 2015) is known in Laos only from Nam Ou Valley in Louangphrabang Province.

Ecology and phenology. Wet granite rocks and moist sandy soils in dry evergreen forest in humid river valleys. Flowers in September - October, fruits in November.

Vernacular name. Som Koung Bai Pak Nok (centella leaf begonia).

Note. Studied plants from Laos have pistillate flowers with two-three tepals and papillose deeply dissected bracts, whereas the pistillate flowers of closely related Begonia pseudosubperfoliata Phutthai et M. Hughes have five tepals and lanceolate, glabrous bracts (Phutthai, Hughes, 2017).

Specimens examined. "Lao PDR, Louangphrabang Province, Ngoi District, $20^{\circ} 46^{\prime} 27.0^{\prime \prime} \mathrm{N}, 102^{\circ} 38^{\prime} 51.9^{\prime \prime} \mathrm{E}, 3$ X 2014, Rodda M., Puglisi C., Souvannakhoummane K. LAO 177" (HNL, E, SING).

\section{Acknoledgements}

We cardinally appreciate the Heads of FOF, HNL, and QBG Herbaria, as well as the Director of Pha Tad Ke Botanical Garden for their kind providing the material for the study. We also thanks the Deutsche 
Gesellschaft für Internationale Zusammenarbeit (GIZ) $\mathrm{GmbH}$ for supporting field studies in Hin Nam No Protected Area and the Environment Protection Fund (EPF) under the Project of Capacity Enhancement of Lao's Natural Sciences, in the SubProject Number PICE-LENS2-010 for supporting of field explorations in Phou Chom Voy Provincial
Protected Area. Laboratory works were carried out in part as the framework of institutional research project of the Komarov Botanical Institute of the Russian Academy of Sciences "The Vascular Plants of Eurasia: the systematics, flora and plant resources" (AAAA-A19-119031290052-1).

\section{REFERENCES / ЛИTEPATУPA}

Averyanov L. V., Nguyen H. Q. 2012. Eleven new species of Begonia L. (Begoniaceae) from Lao PDR and Vietnam. Turczaninowia 15, 2: 5-32.

Averyanov L., Nguyen K. S., Maisak T. 2019a. Plant diversity, flora and vegetation of Hin Nam No Protected Area. Saarbrucken: Lambert Academic Publishing. 431 pp.

Averyanov L. V., Nguyen K. S., Maisak T. V., Nguyen H. T., Nguyen H. Q. 2019b. Two new species of Begonia L. (Begoniaceae) from central Laos. Turczaninowia 22, 2: 134-141. DOI: 10.14258/turczaninowia.22.2.9

Camfield R., Hughes M. 2018. A revision and one new species of Begonia L. (Begoniaceae, Cucurbitales) in Northeast India. European Journal of Taxonomy 396: 1-116. DOI: 10.5852/ejt.2018.396

De Wilde J. J. F. E., Hughes M., Rodda M., Thomas D. C. 2011. Pliocene intercontinental dispersal from Africa to Southeast Asia highlighted by the new species Begonia afromigrata (Begoniaceae). Taxon 60, 6: 1685-1692. DOI:10.1002/tax.606013

Doorenbos J., Sosep M. S. M., De Willde J. J. F. E. 1998. Studies in Begoniaceae VI. The sections of Begonia including descriptions, keys and species lists. Wageningen Agric. Univ. Pap. 98, 2: 1-266.

Gu C. Z., Peng C.-I., Turland N. J. 2007. Begoniaceae. In: Flora of China. Z. Y. Wu, P. H. Raven, D. Y. Hong (eds). Vol. 13. Beijing and St. Louis: Science Press and MBG Press. Pp. 153-207.

Ho P. H. 1991. Begoniaceae. In: An illustrated Flora of Vietnam. Vol. 1(2). Santa Ana, California. Pp. 577-588.

Hong-Bo Ding, Mya Bhone Maw, Bin Yang, Somsanith Bouamanivong, Yun-Hong Tan. 2020a. An updated checklist of Begonia (Begoniaceae) in Laos, with two new species and five new records. PhytoKeys 138: 187-201. DOI: $10.3897 /$ phytokeys. 138.46718

Hong-Bo Ding, Yan-Xiong Gong, Rui Pan, Xiao-Qiang Lu, Yun-Hong Tan. 2020b. A new tuberous species of Begonia L. (Begoniaceae) from southern Yunnan, China. Phytotaxa 474, 1: 81-86. DOI:10.11646/phytotaxa.474.1.8 Hooker J.D. 1899. Begonia hemsleyana. Curtis's Botanical Magazine 125: t. 7685.

Hughes M. 2008. An Annotated Checklist of Southeast Asian Begonia. Edinburgh, Royal Botanic Garden Edinburgh. 164 pp.

Hughes M., Aung M. M., Armstrong K. 2019. An Updated Checklist and A New Species of Begonia (B. rheophytica) from Myanmar. Edinburgh Journal of Botany 76, 2: 1-11. DOI:10.1017/S0960428619000052

Hughes M., Moonlight P. W., Jara-Muñoz A., Tebbitt M. C., Wilson H. P., Pullan M. 2015-. Begonia Resource Centre. Database http://padme.rbge.org.uk/begonia (Accessed at 2 April 2021).

Hughes M., Peng C.-I., Liu Y., Thomas D. C., Phuthai T., Rubite R. R., Girmansyah D., Ardi W. H., Tanaka N., Mui C. Y., Tan J. 2018. Species Portraits. In: Asian Begonia: 300 Species Portraits. M. Hughes, C.-I. Peng (eds). Taipei: KBCC Press: Scotland, Edinburgh: RBGE. 353 pp.

IUCN. 2019. Guidelines for using the IUCN red list categories and criteria, version 14. Prepared by the Standards and Petitions Committee. Available from: http://www.iucnredlist.org/documents/RedListGuidelines.pdf (Accessed: 04 April 2021).

Kiew R. 2005. Begonias Peninsular Malaysia. Natural History Publications (Borneo), Singapore Botanic Gardens and National Parks Board, Singapore. 308 pp.

Kiew R. 2007. Notes on Vietnamese Begonia (Begoniaceae), including three new species. Adansonia 29, 2: 229_ 238.

Kurz W. S. 1873. New Burmese plants. The journal of the Asiatic Society of Bengal 42, 2: 81-83.

Léveillé A. H. 1906. Novitates sinenses. Repertorium specierum novarum regni vegetabilis 2: 113.

Moonlight P. W., Ardi W. H., Padilla L. A., Chung K.-F., Fuller D., Girmansyah D., Hollands R., Jara-Munoz A., Kiew R., Mahardika A., Marasinghe L. D. K., Leong W.-W., Liu Y., O'Connor M., Peng C.-I., Perez A. J., Phutthai T., Pullan M., Rajbhandary S., Reynel C., Rubite R. R., Sang J., Scherberich D., Shui Y.-M., Tebbitt M. C., Thomas D. C., Wilson H. P., Zaini N. H., Hughes M. 2018. Dividing and conquering the fastest growing genus: towards a natural sectional classification of the mega-diverse genus Begonia (Begoniaceae). Taxon 67, 2: 267-323. DOI:10.12705/672.3 
Peng C.-I., Ling C.-W., Yang H.-A., Kono Y., Nguyen H. Q. 2015a. Six new species of Begonia (Begoniaceae) from limestone areas in northern Vietnam. Bot. Stud. 56, 1: 1-23. DOI:10.1186/s40529-015-0089-3

Peng C.-I., Yang H.-A., Kono Y., Jung M.-J., Nguyen T. H. 2015b. Four new species of Begonia (Begoniaceae) from Vietnam: B. abbreviata, B. calciphila, B. sphenantheroides. Phytotaxa 222, 2: 083-099. DOI:10.11646/ phytotaxa.222.2.1

Phutthai T., Hughes M. 2017. Four new species of Begonia (Begoniaceae) from Thailand. Edinburgh Journal of Botany 74, 2: 149-161. DOI:10.1017/S0960428617000051

Souvannakhoummane K., Hughes M., Lanorsavanh S. 2016. Begonia lamxayiana Souvann. (Begoniaceae): a new species from Lao PDR. Thai Journal of Botany 8, 1: 1-5.

Souvannakhoummane K., Lanorsavanh S., Lamxay V. 2018. Two new species of Begonia L. (Begoniaceae) from central Laos. Taiwania 63, 3: 188-194. DOI:10.6165/tai.2018.63.188

Wang W.-G., Xi H.-C., Ma X.-D., Jiang L.-J., Wang X.-J., Shi J.-P., Shen J.-Y. 2019. Begonia austroyunnanensis, a new species of Begonia (Begoniaceae) from Yunnan, China. Taiwania 64, 4: 363-366. DOI:10.6165/tai.2019.64.363

Yang C.-J., Tagane S., Souladeth S., Okabe N., Hu J.-M., Yahara T. 2018. Flora of Nam Kading National Protected Area III: Begonia namkadingensis (Begoniaceae), a new species in limestone area. Phytotaxa 334, 2: 195199. DOI:10.11646/phytotaxa.334.2.8

Yang Z.-Z., Zhou S.-S., Li Z.-H., Wang J., Chen W.-H., Shui Y.-M. 2015. Two new records of Begonia L. (Begoniaceae) from China. Plant Diversity and Resources 37, 4: 425-427. DOI: 10.7677/ynzwyj201514131 